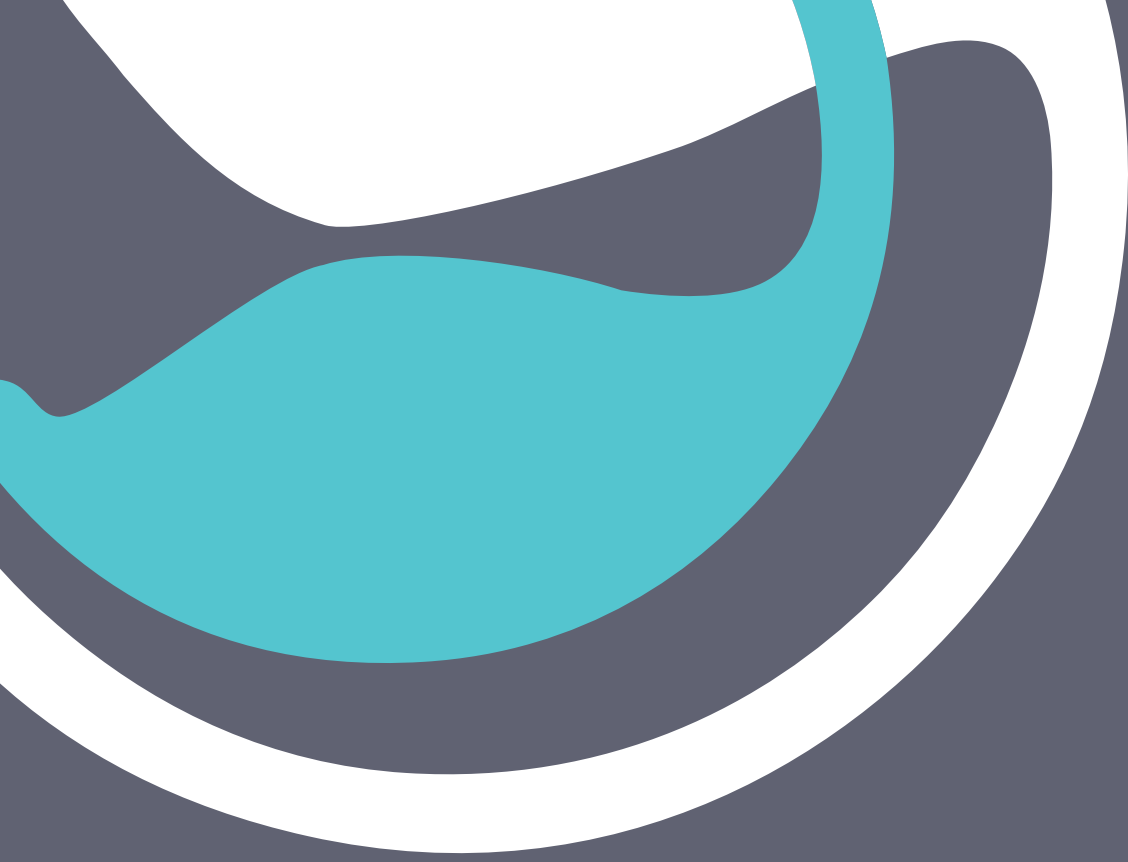

wWw.ictd.ac

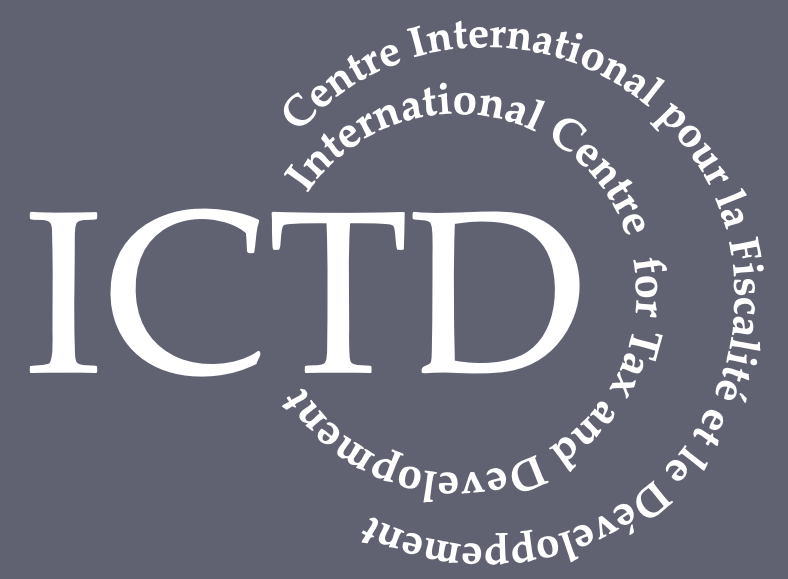

Working Paper 15

\title{
Obstacles to Increasing Tax Revenues in Iow Income Countries
}

Mick Moore

December 2013

A joint paper by the International Centre for Tax and Development (ICTD) and the United Nations Research Institute for Social Development (UNRISD)

This paper has been co-funded by the Swiss Agency for Development and Cooperation (SDC) and as part of the IDS project 'The Governance of Service Delivery 


\section{About ICTD}

The International Centre for Tax and Development is a global policy research network dealing with the political economy of taxation policies and practices in relation to the poorer parts of the world.

Our operational objectives are to generate and disseminate relevant knowledge to policymakers and to mobilise knowledge in ways that will widen and deepen public debate about taxation issues within poorer countries. Our ultimate objective is to contribute to development in the poorer parts of the world and help make taxation policies more conducive to pro-poor economic growth and good governance.

The ICTD is funded by the UK Government's Department for International Development (DFID) and the Norwegian Agency for Development Cooperation (Norad), a directorate under the Norwegian Ministry of Foreign Affairs (MFA).

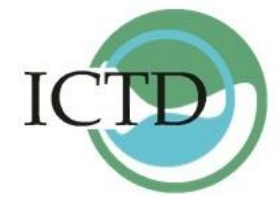

For further information, please contact:

ICTD at IDS,

Brighton BN1 9RE,

United Kingdom

T: +44 (0)1273 $606261 \mathrm{E}:$ info@ictd.ac

W: www.ictd.ac

\section{About UNRISD}

The United Nations Research Institute for Social Development (UNRISD) is an autonomous research institute within the UN system that undertakes multidisciplinary research and policy analysis on the social dimensions of contemporary development issues. Through our work, we aim to ensure that social equity, inclusion and justice are central to development thinking, policy and practice.

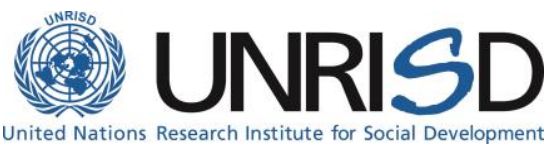

For further information, please contact:

UNRISD, Palais des Nations

1211 Geneva 10, Switzerland

Tel: +41 (0)22 9173020

info@unrisd.org

www.unrisd.org

\section{About SDC}

The Swiss Agency for Development and Cooperation (SDC) is Switzerland's international cooperation agency within the Federal Department of Foreign Affairs (FDFA). In operating with other federal offices concerned, SDC is responsible for the overall coordination of development activities and cooperation with Eastern Europe, as well as for the humanitarian aid delivered by the Swiss Confederation.

The goal of development cooperation is that of reducing poverty. It is meant to foster economic selfreliance and state autonomy, to contribute to the improvement of production conditions, to help in finding solutions to environmental problems, and to provide better access to education and basic healthcare services.

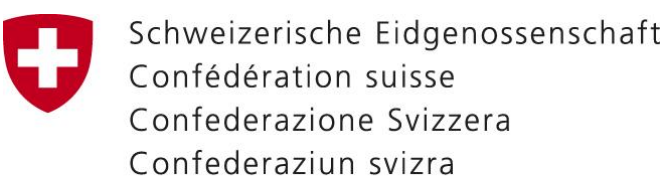

Swiss Agency for Development and Cooperation SDC
For further information, please contact:

SDC - Head office

Freiburgstrasse 130, 3003 Berne

Phone: +41313223475

info@deza.admin.ch 
ICTD Working Paper 15

Obstacles to Increasing Tax Revenues in Low Income Countries

Mick Moore

December 2013 
Obstacles to Increasing Tax Revenues in Low Income Countries Mick Moore

ICTD Working Paper 15

First published by the International Centre for Tax and Development in December 2013

(c) Shared between Institute of Development Studies, UNRISD and SDC 2013.

ISBN: 978-1-78118-141-6

A catalogue record for this publication is available from the British Library.

All rights reserved. Reproduction, copy, transmission, or translation of any part of this publication may be made only under the following conditions:

- with the prior permission of the publisher; or

- with a licence from the Copyright Licensing Agency Ltd., 90 Tottenham Court Road, London W1P 9HE, UK, or from another national licensing agency; or

- under the terms set out below.

This publication is copyright, but may be reproduced by any method without fee for teaching or nonprofit purposes, but not for resale. Formal permission is required for all such uses, but normally will be granted immediately. For copying in any other circumstances, or for reuse in other publications, or for translation or adaptation, prior written permission must be obtained from the publisher and a fee may be payable.

Available from:

International Centre for Tax and Development, Institute of Development Studies,

Brighton BN1 9RE, UK

Tel: +44 (0) 1273915758 Fax: +44 (0) 1273621202

E-mail: bookshop@ids.ac.uk

Web: www.ids.ac.uk/ids/bookshop

IDS is a charitable company limited by guarantee and registered in England (No. 877338) 


\title{
Obstacles to Increasing Tax Revenues in Low Income Countries
}

\author{
Mick Moore
}

\section{Summary}

This paper is focused on the question: why do the governments of low income countries not raise more tax revenues? Two different but complementary approaches are used to answer it. The first approach is comparisons: among countries today, and within countries over time. This approach tends to generate relatively conservative answers to the central question. It leads to an emphasis on the 'sticky' nature of the taxation. For any individual country in 'normal times' - i.e. excluding situations of war, major internal conflict, the collapse or rapid reconstruction of state power - revenue collections, measured as a proportion of GDP, do not change much from year to year. This is partly because effective taxation systems require a great deal of coordination and cooperation between revenue agencies and other organisations, both inside and outside the public sector. It is hard quickly to improve the effectiveness of a complex organisational network. The 'stickiness' of tax collections also reflects the fact that the overall tax take - i.e. the proportion of GDP raised as public revenue - is to a significant degree determined by the structure of national economies. For logistical reasons, it is much easier to raise revenue from economies (a) that are high income, urban and non-agricultural and (b) where the ratio of international trade to GDP is high. The government of the average low income country raises less than 20 per cent of GDP in revenue. It makes no sense for such governments to aim to match OECD tax takes of 30-45 per cent of GDP.

The comparative and historical approach also draws attention to the political constraints on the capacity of governments to raise more revenues. These political constraints are quite variable across time and space. The most familiar is the capacity of wealthy people and companies to influence opaque processes of tax policy formulation and administration to ensure that they pay less in taxes than most other people would consider reasonable. But this kind of interest group politics is only one of the sets of political phenomena we need to take into account. Another is that the organisations that collect taxes often engage in a considerable amount of rent-taking. They make money illegally for their own staff, often handing over some of it to their political masters. In the process of making money illegally, they often cut deals with taxpayers, to the double detriment of the public treasury. These practices tend to bring tax collection into disrepute, and decrease overall willingness to pay. The tax system also serves another political purpose. The ability of governments to grant tax exemptions - i.e. to exclude specific companies, industries or individuals from tax entirely, typically on the grounds that this is an 'incentive' to bring in more investment - is in some countries a significant instrument through which governments command support and political financing. The tax losses are enormous. Finally, the design of a country's political and government institutions can sometimes have a significant effect on its capacity to tax. In particular, if the authority to raise taxes is institutionally and politically very separate from the authority to spend public money, the political capacity to raise revenues is likely to be reduced.

The second approach to answering the central question of this paper is to examine the potential benefits of reforms in tax policy and administration. This generates more optimism about the possibilities of raising additional revenues. The paper deals in particular with three reform issues. The first is the scope for the governments of low income countries to obtain more revenue by better taxing transnational economic transactions, above all those involving large transnational companies. The picture here is very unclear, not least because attitudes, 
understanding and policies are changing quite rapidly at the global level. Low income countries might benefit from a wide range of reforms now on global policy agendas. But they would be unwise to rely heavily on such an outcome. The second issue concerns the scope to adopt more widely a bundle of what I term 'advanced tax administration practices'. Although they originate mainly in OECD countries, these 'advanced tax administration practices' have already had a significant impact in many low income countries, and are not intrinsically inappropriate to their circumstances. But in one respect they do not address the needs of low income countries: they do not tackle the problem of the gross under-taxation of land and property. This is the third policy reform area. The case for substantial taxes on land and property is compelling. The obstacles are both political and institutional.

If we look for specific 'revenue gaps' in low income countries, the most evident are: the large amounts of potential tax that are given away routinely by governments in the form of unjustified 'tax incentives'; the under-taxation of land and property; evasion by those transnational corporations that use transfer mispricing to relocate their profits to the places in the world where they pay little or no tax; the under-taxation of the profits of mining companies (at least when we take into account the prices for minerals over the past decade); and the under-taxation of the wealth and incomes of very rich individuals. But the more visible revenue gaps are not always the most important. The productivity of VAT in some countries is low because the system is poorly designed. The easiest way to raise more revenue might be to make a series of apparently highly technical changes to the VAT. And even the visible revenue gaps might not always be best tackled frontally. There will be moments when that seems right. But a frontal assault is not always the best way to win a tax war. Effective tax reform typically requires large doses of political cunning, and may best be wrapped in the soothing - or even soporific - language of 'tax administration improvements'. If employed intelligently, the obscure concept of 'broadening the tax base' could be used in many countries significantly to narrow the five big 'revenue gaps' listed above. Tax is simultaneously both a highly political and a highly technical issue. It is not useful to make advance judgements about how technical knowledge and politics might best be combined to raise more revenue in any specific context.

Keywords: tax, tax administration, revenue, low income countries, politics, rent-taking

Mick Moore is a Professorial Fellow in the Governance Team at IDS and Chief Executive Officer of the International Centre for Tax and Development. He specialises in the interaction between money, public finance and politics. 


\section{Contents}

Summary 3

$\begin{array}{ll}\text { Acknowledgements } & 6\end{array}$

$\begin{array}{ll}\text { Acronyms } & 6\end{array}$

$\begin{array}{ll}\text { Table } 1 & 7\end{array}$

Introduction 8

$1 \quad$ The constraints arising from economic structure 13

1.1 The effects of income and the sectoral composition of the economy 14

$\begin{array}{ll}1.2 \text { The effects of international trade } & 16\end{array}$

$\begin{array}{ll}1.3 \text { Economic structure and the tax take; conclusion } & 17\end{array}$

$2 \quad$ The use of the tax system for rent-taking 17

3 The use of the tax system as a direct instrument of rule 20

$4 \quad$ The influence of interest group politics 22

4.1 The effects of high inequality on the tax take 23

4.2 Fiscal contracting 24

$5 \quad$ The configuration of governing institutions 25

6 The difficulties of taxing transnational transactions 26

$7 \quad$ Insufficient use of advanced tax administration practices 28

7.1 Organisation by taxpayer segment and function, not tax type 28

$\begin{array}{ll}7.2 \text { Establishing and verifying trust } & 29\end{array}$

$\begin{array}{ll}7.3 \text { Making tax paying easy and impersonal } & 29\end{array}$

$8 \quad$ The property tax issue 30

9 Conclusions 32

$\begin{array}{ll}\text { References } & 33\end{array}$ 


\section{Acknowledgements}

This paper was commissioned for the UNRISD research project, Politics of Domestic Resource Mobilization for Social Development. The project seeks to contribute to global debates on the political and institutional contexts that enable poor countries to mobilize domestic resources for social development. It examines the processes and mechanisms that connect the politics of resource mobilization and demands for social provision; changes in state-citizen and donorrecipient relations associated with resource mobilization and allocation; and governance reforms that can lead to improved and sustainable revenue yields and services. For further information on the project visit www.unrisd.org/pdrm.

The paper has been co-funded by the Swiss Agency for Development and Cooperation (SDC) as part of the IDS project 'The Governance of Service Delivery'.'

\section{Acronyms}

BRICS Group of important emerging economics (Brazil, Russia, India, China, South Africa)

GDP Gross Domestic Product

G8 An influential 'club' of 8 nations that meet annually

G20 An influential 'club' of 20 nations that meet annually. It is more representative of emerging economies than the G8 group

IMF International Monetary Fund

OECD Organisation for Economic Cooperation and Development

PAYE Pay As You Earn

UN United Nations

UNRISD United Nations Research Institute for Social Development

VAT Value Added Tax 
Table 1

Table 1 Summary statistics on sources of government revenue, by country category

\begin{tabular}{|c|c|c|c|c|c|}
\hline Country category: & Low income & $\begin{array}{l}\text { Lower-middle } \\
\text { income }\end{array}$ & $\begin{array}{l}\text { Upper-middle } \\
\text { income }\end{array}$ & $\begin{array}{l}\text { High income } \\
\text { non-OECD* }\end{array}$ & $\begin{array}{l}\text { High income } \\
O E C D\end{array}$ \\
\hline Number of countries: & (37) & $(48)$ & (41) & (18) & $(30)$ \\
\hline a. Government revenue as a \% of GDP & 18 & 26 & 29 & 34 & 42 \\
\hline $\begin{array}{l}\text { b. Government revenue, excluding grants, as a \% } \\
\text { of GDP }\end{array}$ & 15 & 26 & 28 & 34 & 41 \\
\hline $\begin{array}{l}\text { c. Government taxes as a \% of GDP (i.e. excludes } \\
\text { non-tax revenue) }\end{array}$ & 13 & 18 & 21 & 16 & 35 \\
\hline d. Taxes as a \% of total government revenue & 71 & 67 & 73 & 46 & 85 \\
\hline d. Income taxes as a \% of GDP & 4 & 5 & 5 & 6 & 13 \\
\hline e. Corporate income taxes as a \% of GDP & 2 & 3 & 3 & 2 & 3 \\
\hline f. Personal income taxes as a \% of GDP & 2 & 2 & 2 & 3 & 10 \\
\hline g. International trade taxes as a $\%$ of GDP & 4 & 5 & 5 & 3 & 1 \\
\hline $\begin{array}{l}\text { h. Taxes on goods and services, including VAT, as } \\
\text { a \% of GDP }\end{array}$ & 5 & 6 & 7 & 5 & 11 \\
\hline $\begin{array}{l}\text { i. Corporate income taxes }(\mathrm{ClT}) \text { as a \% of } \\
\text { government revenue }\end{array}$ & 12 & 11 & 12 & 7 & 7 \\
\hline $\begin{array}{l}\text { j. Personal income taxes (PIT) as a \% of } \\
\text { government revenue }\end{array}$ & 9 & 7 & 8 & 8 & 23 \\
\hline k. Ratio of CIT to PIT revenue & 1.4 & 1.5 & 1.5 & 0.9 & 0.3 \\
\hline
\end{tabular}

Source: IMF (2011, appendix table 2).

Note: The numbers show the means within each category and relate to recent years.

* These are mainly countries with high levels of income from energy or mineral extraction. 


\section{Introduction}

\section{Approach}

This paper is focused on the question: why do the governments of low income countries not raise more tax revenues? There is a wide range of potential answers to this question. Some are purely speculative. Others are based on solid evidence. And many lie somewhere inbetween. In sorting out what we reliably know from a wide range of propositions about what might be significant, I have used two different but complementary approaches.

\section{Comparison: realism}

The first approach, that is most evident in the early sections of the paper, is comparison, both among countries today, and within countries over time. This reflects my awareness both of the very political character of taxation and, more specifically, the 'sticky' nature of the tax collection business: in normal circumstances - i.e. excluding episodes of very rapid economic growth, war, major conflict, or the collapse of political authority - the total revenues collected by governments vary little from year to year. ${ }^{1}$ If you know how much revenue a government collected in 2013 then, making allowance for inflation, you can reliably predict how much it will collect in 2014. This stability is partly because, especially in low income countries, the behaviour of tax agencies is governed by the annual incremental collection targets set by ministries of finance. But it also reflects a more structural factor. Revenue agencies are highly 'networked' organisations, dependent on active cooperation from a wide range of other stakeholders, including ministries of finance, commerce and justice; authorities responsible for registering motor vehicles, businesses and property; public utilities; public procurement agencies; the police, judiciary and public prosecutor; border security forces; tax agencies in other countries; banks; employers; large companies; insurance companies; company registrars; business associations; and professional associations of accountants and auditors (Bird and Zolt 2008; Vázquez-Caro and Bird 2010). ${ }^{2}$ New tax policies and administrative improvements within a revenue agency may have very limited impact if not supported by corresponding changes in the network. Waves of enthusiasm for reforming tax policy and administration in one direction or another tend to leave few detectable footprints in the historical tax statistics. ${ }^{3}$ Tax policy reforms and changes in prevalent ideologies about how tax should be practised are generally more abundant than substantial changes in tax performance.

It follows that we should be sceptical of claims that any specific tax innovation could lead to major increases in revenue collection in low income countries in the short term, i.e. within periods measured in years rather than in decades. Indeed, at present there seems to be very little realistic prospect of any major change in tax regimes comparable in magnitude, for example, to the introduction of VAT in low income countries over the past three decades. ${ }^{4}$ The

Incidents of more or less total state failure - i.e. collapses in the effective authority of government - were responsible, for example, for big falls in revenue collection in Bolivia, Ghana, Peru and Uganda in the 1980s, and in Rwanda in the early 1990s. Conversely, unusually large and sustained increases in the ratio of revenue collections to GDP were achieved in Brazil under President Cardoso (1995-2003).

2 For an illustrative table of the extent to which Latin American tax administrations use some of the main third party sources of information on actual or potential taxpayers, see Corbacho et al. (2013: Table 6.2).

Bird (2012); Keen (2012); Vázquez-Caro and Bird (2010).

Overall, it took more than half a century for VAT to spread from France in the mid-1950s to cover most of the world today. The experience of introducing VAT has been broadly positive. There is a large literature on VAT, and much criticism of the fact that it has been actively promoted in developing countries by the IMF in particular. The major criticism is that VAT is regressive because it is a tax on consumption. There is no space here to evaluate all the arguments for or against VAT. It is potentially a very effective means of increasing tax revenues, and has generally been used in this way in low income countries. The introduction of VAT has been a useful stimulus to broader tax administration forms in many low income countries. And the alleged regressive impact is not actually evident in the 
'flat tax' was briefly fashionable about two decades ago, and was introduced in a few European ex-Communist countries, but it is clear that it is in no sense a 'silver bullet'. A number of Latin American countries continue to experiment with bank transaction taxes. While they raise a little revenue, their effectiveness declines over time as they encourage businesses and people to find ways of by-passing banks (Corbacho et al. 2013: chapter 12). The area of greatest current uncertainty is in the taxation of international economic transactions. It is almost certain that the governments of many low income countries are deprived of large sums of legitimate revenue as a result of the legal and accounting fictions and occasional outright frauds - practised by mining companies and other transnational companies (Section 6). Formally, and notably through recent statements from the G20, the G8, the OECD and other international actors, this has become a priority area for international attention. But substantial reductions in transnational tax avoidance require sustained collective action by the governments of many countries, especially those of the OECD, and the large emerging middle and low income countries (broadly, the BRICS). Regardless of their public espousal of such cooperation, almost all governments pursue individualistic policies designed to maximise their national share of investment and tax revenue. In general, the countries whose cooperation is most needed to make international collective action effective are those best placed to maximise their individual shares of investment and tax revenue by pursuing competitive policies. There is very little global governance in the public revenue field. There is no revenue equivalent to the World Trade Organisation, which has mitigated similar problems in respect of trade by creating an authoritative forum in which a large number of competing national interests can be reconciled through long negotiation. ${ }^{5}$

There are also grounds to suspect that the benefits of wider international cooperation in taxing transnational economic transactions might accrue more to larger BRICS-type countries than to more typical low income countries. The governments and tax authorities of the larger economies - including for example Indonesia and South Africa as well as Brazil, Russia, India and China - have more bargaining power in relation to inward transnational investors. This has been evident recently in the extent to which the Brazilian, Chinese and Indian tax authorities have become assertive in their interpretations of (complex) principles, rules and laws around transfer pricing, i.e. the accounting prices used for non-market international transactions between related companies (UNDESA 2013: chapter 10). ${ }^{6}$ Partly because they are larger and can call on a wider range of specialist staff, the tax authorities of the BRICS and similar countries tend to be more competent. They are better placed than the tax authorities of the more typical low income country to benefit reforms proposed by the G8/G20, including proposals to make the exchange of information among national tax authorities much easier. While recognising that the prospects for significant reform of the international tax regime are better now than they have been for a long time, we should be sceptical about the extent to which formal commitments will result in effective action, and about the likelihood that smaller low income countries in particular will reap major benefits. ${ }^{7}$

(poor) available figures. See Bird and Gendron (2007); Ebrill et. al. (2001, 2002); Gemmell and Morrissey (2005); Keen (2007); and Keen and Lockwood (2010).

$5 \quad$ The OECD is the only international organisation directly representing governments that has a substantial revenue competence and remit. It has been accorded a central role in designing the policies and programmes needed to operationalise the formal commitments being made by the G8 and the G20 in respect of revenue issues. While it has attempted to be more inclusive in its discussions of international tax issues, the OECD only represents 34 high income economies.

$6 \quad$ The accepted principle is that the transfer prices used for taxation purposes should be the prices that would pertain had there been an 'arms length' market transaction. This leaves considerable scope in practice for companies to choose the prices at which they book transnational transactions - and thus to choose where in the world they wish their profits to appear for taxation purposes. It is widely believed that transfer mispricing is the single most important mechanism for transferring profits from low income countries. For more information on transfer pricing and mispricing, see various chapters in Christian Aid (2010); European Commission (2011); Ernst and Young (2013); and Reuter (2012).

$7 \quad$ They could possibly be losers. If the tax administrations of the OECD and BRICS-type countries develop better tools to identify and deter practices like transfer mispricing, transnational corporations could focus more of their tax avoidance efforts on low income countries with relatively weak tax administrations. 


\section{The scope for reform: optimism}

Comparisons, history and realism about the politics of taxation encourage us to be sceptical about the prospects for radical changes in the ways in which governments of low income countries collect taxes, or radical increases in their capacity to increase revenues. But that does not amount to pessimism about the scope to do better on both counts. My second approach to answering the central question in this paper is to examine, mainly in Sections 6 to 8 , the potential benefits of reforms in tax policy and administration. There is considerable scope for: better taxing transnational economic transactions (Section 6); extending the adoption of a bundle of what I term 'advanced tax administration practices' (Section 7); and taxing property (Section 8).

\section{The tax take: the broad picture}

What proportion of GDP do governments appropriate through taxation? Colloquially and in this paper that figure is called the tax take. Excluding aid and other non-tax revenue, that figure varies from an average of 13 per cent for low income countries and 35 per cent for high income OECD countries (Table 1, row c.). Statistics on the tax take are widely used, especially to compare countries, and often with the implication that the size of the tax take is a useful way to evaluate the revenue collecting performance of governments. However, we need to exercise caution in drawing conclusions from these numbers:

- First, and especially for low income countries, measures of the tax take may not be very reliable. The revenue collection figures themselves often vary by source, and are not as accurate or standardised as one might expect for what appears to be a strategic economic statistic. ${ }^{8}$ Estimations of the size of GDP are also contentious and unstable (Jerven 2013). For example, a recent re-estimation of the size of Ghana's GDP produced a large apparent decline in the national tax take. ${ }^{9}$

- Second, as is explained in Section 1, tax takes for individual countries are to a significant degree given by the structures of their economies, especially per capita income levels. Tax take figures alone, unadjusted for features of economic structure, are not valid as measures of tax collection effort or performance.

- Third, it is important to be aware of the distinction that appears almost universally in public accounts between governments' tax revenues and their non-tax revenues. Most non-tax revenues - like user fees, royalties from exploitation of natural or other resources, income from state-owned enterprises, and seigniorage from the printing of currency - derive from government's control over tangible assets. For accountants and economists, the biggest contemporary problem in distinguishing tax from non-tax revenue relates to compulsory social security contributions, paid by formal sector employees and/or their employers. Should they be defined and accounted as tax or non-tax revenues? ${ }^{10}$ They typically comprise elements of both. For the purposes of this chapter, the fuzziness of the conceptual, legal and accounting boundaries between tax and non-tax revenues is of little significance. ${ }^{11}$ I define taxation politically as the institutionalised, coercive transfer of income to rulers from the ruled. Much non-tax revenue falls into this category. My concern is with government revenue generally,

\footnotetext{
$8 \quad$ The IMF is the main source for such data. They have recently made some improvements in their series (Seiferling 2013). The International Centre for Tax and Development is in the process of producing a more comprehensive and more thoroughly sanitised data set on government revenue in low income countries than those sets currently available.

$9 \quad$ This phenomenon is not restricted to low income countries. For example, the revised US national income statistics published in July 2013 were also significantly different from the earlier series, and implied a (small) change in the level of the tax take.

10 The problem is that in many countries social security spending is in principle financed only from contributions (from employers, employees etc.) and nominally ring-fenced from general government fiscal activities, while in practice they are partially or completely integrated.

$11 \quad$ Non-tax revenues are relatively more important for sub-national governments.
} 
excluding aid. But those unfamiliar with revenue issues should be aware of the dangers of conflating figures on total government revenue with figures on tax revenue. ${ }^{12}$

All that said, there are good practical reasons why most low income countries should aim to increase their tax takes by a few percentage points of GDP. These reasons have been articulated in a recent policy paper from the IMF (2011). They hinge on the potential collective benefits of greater public spending on social welfare and economic infrastructure. This paper starts from the assumption that the governments of most low income countries should increase the tax take. This may not be true in every case. Some governments may have as much revenue as they can productively spend, and others might do less damage if they had less money at their disposal. But in the most representative cases, higher tax revenues, better and more fairly collected, are desirable.

\section{The central role of bargaining}

Why do the governments of low income countries not raise more money in tax revenue? At the most abstract level, there is an obvious answer: taxation is the process of extracting money from people and organisations with no promise of any specific reciprocity. Resistance to this extraction is normal, natural, and desirable. A world in which governments could rely on taxpayers to meet unlimited revenue demands would be poverty stricken and ill-governed to an unimaginable degree. Resistance to attempts to extract taxes forces governments to explain their case for revenue, and to engage in bargaining of various kinds with taxpayers. It has played a significant role in the development of efficient, accountable governance. ${ }^{13}$

The collection of taxes depends ultimately on the willingness and ability of governments to use force. Conversely, force alone is not enough, and may be counterproductive. The efficiency and overall effectiveness of modern tax systems depends heavily on the extent of quasivoluntary compliance, i.e. the degree to which taxpayers will cooperate with tax authorities and pay what is due without engaging in high levels of resistance or delay. We might also term this 'grudging compliance' (Tilly 2005).

It is not very helpful, either analytically or from a policy perspective, to approach the problem of low tax revenues by complaining that taxpayers are failing to meet their legal obligations, or to take the view that the art of successful tax collection is based solely or primarily on finding ways of enforcing those obligations. Effective enforcement is essential to efficient revenue collection. Most of us will comply only if we know that, in the last resort, we can be coerced. There are altruistic people who pay their taxes more willingly because they believe it is the right thing to do. Their numbers would however implode if they believed that many fellow citizens were not paying their share and getting away unpunished. ${ }^{14}$ Law and obligation are essential tools that make the revenue collection machine operate. But the machine itself is constructed through politics and bargaining. Processes of bargaining and exchange are central to the macro-level decisions about the design of tax regimes - the types of taxes levied, the rates applied, the legal definitions of the concepts used, the accounting practices accepted, the assessment and collection procedures followed - and to the more micro-level operational decisions about which taxpayers will be pursued by the tax authorities, how, and how far. Appreciating the role of these bargaining processes is essential to any reform project. ${ }^{15}$

\footnotetext{
12 Further, some official data on total government revenues covers both central and sub-national government, while some relates only to central government.

Bates and Lien (1985); Gervasoni (2010); Moore (2008a, 2008b, forthcoming); Prichard (2009); and Tilly (1992).

Survey evidence conforms to expectations. People are less willing to pay tax if they think other people are evading (Torgler 2005).

Some social scientists (e.g. Zolberg 1980) use the term 'strategic interaction' for what I have called 'bargaining'. For a broader discussion of bargaining, see Moore (2008a).
} 
Tax regimes are bargained in the sense that they are either: (a) designed in formal or informal collaboration with the potential taxpayers (including those with the capacity to avoid becoming taxpayers); or (b) continuously reshaped as a result of either political pressures from taxpayers or the perceptions of tax authorities about how taxpayers have or will respond to changes in the regime. ${ }^{16}$

Similar processes of bargaining and exchange occur continuously at the level of implementation - assessment, collection, auditing, dispute resolution, etc. Tax collectors, taxpayers, and the diverse tax intermediaries (lawyers, accountants, fixers) have the capacity to both benefit and damage their counterparts. If taxpayers are generally resistant and uncooperative, they can make it costly for tax collectors to extract money from them. Taxpayers may be able to purchase or otherwise mobilise support from politicians. But tax collectors can also impose costs on non-cooperative taxpayers, including through: (a) demanding extensive documentation; (b) repeated audits; (c) making large assessments that can only be contested in court or, worse, in appeals processes effectively controlled by the tax authorities themselves; or (d) physically detaining shipments of goods, especially at Customs (Moore forthcoming).

In most cases, taxpayers and tax collectors have an interest in establishing cooperative relationships and reaching some kind of informal equilibrium agreement about how much tax will be paid in given circumstances. The extent to which these 'equilibrium agreements' are designed to meet either (a) the personal and institutional interests of the tax collectors or (b) the interests of the public treasury, is central to the effectiveness and legitimacy of different tax systems (Section 2). Even where the public interest is uppermost, tax collectors do not set out solely or dominantly to enforce in detail the legal tax obligations of every taxpayer. They set out to collect what they believe they can reasonably or sensibly collect, taking into account such factors as: (a) the additional revenue that might result if they put more effort into communicating with or investigating individual taxpayers; (b) the incentives they face to keep taxpayers cooperative by not irritating them; and (c) at the high end of contemporary tax practice, information from statistically-based assessments of the likelihood that particular taxpayers will be significant defaulters. In every country, a great deal of theoretically tax-liable income, transactions or assets escape the tax net. The important differences lie in whether these resources are not taxed because the administrative costs of pursuing them or of irritating taxpayers are too high, or whether political influence and corruption play a big role in enabling some people and companies to escape their obligations.

One of the important implications of the prevalence of informal bargaining in tax policy and administration is that, even in the absence of corruption or the direct use of political connections, tax regimes tend to be biased in favour of those taxpayers with the greatest bargaining power, i.e. those who can most easily evade or avoid taxes, and whose cooperation is most valuable in the long term. Provided they can find other taxpayers to take up the burden, governments routinely 'under-tax' - or find some other way of rewarding their major reliable sources of tax revenue. ${ }^{17}$

\section{Classifying the obstacles to increasing tax revenues}

There are many partial answers to the question: why do the governments of low income countries not raise more tax revenues? If they are to be practically useful, the answers need to be classified as well as listed. They could be classified in many different ways. The classification used here was shaped by the purpose of the paper: to provide UNRISD with

Daunton's (2001) account of the evolution of taxation in nineteenth century Britain illustrates this point in detail. For a theoretical and empirical elaboration of this argument, see Gehlbach (2008). For supportive evidence from contemporary China, see Choi (2009). 
some guidance in researching the question of how tax revenues could be increased. I have classified the obstacles to higher tax collection into eight main groups. In presenting them, I start with the more fundamental economic and political factors that seem to explain both the stickiness of tax takes within individual countries and the long term variation in tax takes among countries. I then move to issues that are both more 'technical' and, in most cases, provide the greatest scope for positive policy change in the medium term. The eight sets of obstacles, which are discussed in Sections 1 to 7, are:

- The constraints arising from economic structure

- The use of the tax system for rent-taking

- The use of the tax system as a direct instrument of rule

- The influence of interest group politics

- The configuration of governing institutions

- The difficulties of taxing transnational transactions

- Insufficient use of advanced tax administration practices

- The property tax issue.

There is some inevitable overlap among these categories: some issues could appear under two or more heads.

Note that I have not tried to list those factors that are somewhere believed consistently to affect revenue raising but do not in practice seem to do so. Possibly the most important among these is foreign aid. There is a widespread view that aid will to some degree act as a substitute for revenue-raising on the part of recipient governments: the more aid governments receive, the less effort they will put into raising their own revenues (see, for example, Knack 2009). This proposition may be true. But the evidence generally does not seem to support it. Insofar as we have evidence, it seems to point in all directions. We do not know how aid affects the local tax effort. The relationships are likely complex, and dependent on the type of aid, who is giving it, why, how, and in what circumstances (Prichard et al. 2012).

Finally, with the exception of property taxes (Section 8), I have not dealt with the question of whether particular types of taxes are especially appropriate to low income countries. Individual specialists sometimes have strong views about the advantages of, for example, flat taxes, bank turnover taxes or VAT to low income countries. However, as I explained above, radical changes in tax regimes do not seem to be on the agenda at present. We can assume that, for the foreseeable future, the tax collectors in most low income countries will continue to depend principally on some mixture of the revenue sources with which they are currently familiar: corporate and personal income taxes; Customs duties; VAT (or general sales taxes); excise duties (levied on commodities like fuel, tobacco and alcohol); specific transactions taxes (stamp duties); social security contributions; and a host of other minor sources.

\section{The constraints arising from economic structure}

The governments of low income countries raise significantly less of their GDP in taxes (and in non-tax revenues) than do the governments of richer countries. This is not a new phenomenon. To the contrary, it appears to have been a constant feature in economic history since sufficient data became available to make such calculations possible. The proposition that the proportion of national income collected as taxes tends continually to increase as countries become richer was formulated as Wagner's Law in 1877. It has proven to be one of the more robust and longstanding empirical propositions in social science. In 
fact, econometric analyses consistently demonstrate that two sets of variables relating to the structure of national economies explain a large proportion of variations in the tax take. ${ }^{18}$ The first set is average per capita income levels and associated measures of the extent of urbanisation and the size of the non-agricultural economy. The second set is measures of openness to international trade: typically the ratio of imports and exports to GDP.

\subsection{The effects of income and the sectoral composition of the economy}

Why do per capita income levels, urbanisation and non-agricultural occupations consistently predict high tax takes? Wagner believed that the motive force lay in steadily increasing popular demands for public spending to allay the adverse effects of industrialism and urbanisation. These factors may play some role, but the consistency of the statistical relationship between tax take and these features of economic structure, both over time and among countries, suggests the primary role of a more structural and less immediately political explanation. In sum, tax takes are low in low income countries because the structure of their economies makes taxing difficult.

One important dimension of economic structure is the high incidence in low income countries of economic relationships of the kind summed up in the term 'informal sector'. Informal economic transactions are hard to tax almost by definition. ${ }^{19}$ This is especially true of labour markets. Because the governments of the wealthier and more capitalist OECD countries require employers to operate PAYE (Pay As You Earn) systems to collect personal income taxes from employees, personal income taxes are their largest single source of public revenue. Social security contributions, mostly also collected and paid by employers, are also significant. By contrast, the governments of low income countries depend more on taxing companies. The ratio of corporate to personal income tax revenues is $0.3: 1$ in the high income OECD countries, and 1.4:1 in the low income countries (Table 1, row k). However, informality is but one aspect of the differences in economic structure between high and low income economies. To understand the broader picture, it is useful to begin with a general look at the logistics of the taxing process. ${ }^{20}$

There is a developmental logic in tax systems, which can be expressed in terms of a contrast between two (idealised) modes of assessing the liabilities of individual taxpayers: physical verification and accounts-based verification. Physical verification can be considered to be the original mode. It has typically been used in the collection of land and crop taxes, property taxes, customs duties, sumptuary taxes on conspicuous consumption, and excise taxes on the production of scarce consumer items like salt, tobacco and alcohol. Physical verification is almost inevitably associated with the merging of assessment with collection: the same person who assesses taxpayers' liabilities also collects the money from them. For this reason, physical verification is typically associated with malfeasance: collectors use their power to extort money from the taxpayer and/or to cheat the exchequer.

Accounts-based verification, which has its roots mainly in corporate and personal income or profits taxes, creates three developmental opportunities. One is the employment of revenue agents whose skills lie more in accounting and law rather than in muscle power and force. The second is the increased scope for separating the process of assessing tax liabilities from the task of actually collecting the money due, thus reducing the scope for extortion or corruption. The third, which applies mainly to digitalisation, is the enormous potential for improving the level and efficiency of collection by matching data from different sources. Some tax agencies

\footnotetext{
18 For a recent summary of a long series of statistical analyses of these issues, see Gupta (2007: Appendix D) and, for more recent reconfirmation, see Pessino and Fenochietto (2010).

For an excellent recent review of the literature on this topic, see Joshi et al. (2012).

The analysis in the following paragraphs derives immediately from Moore (2013). A wide range of sources are cited there.
} 
in low-income countries still do little data analysis beyond tracking their own collection performance. Digitalisation makes possible data matching and analysis exercises that greatly change working methods and improve outcomes for both tax collectors and taxpayers (Bird and Zolt 2008).

As economies become less agrarian, more marketised, and better recorded - first on paper and then digitally - there is a 'natural' trend toward accounts-based taxation. Accounts-based taxation has the potential greatly to reduce the friction that inevitably exists between taxpayers and tax collectors. It is less adversarial and more efficient than taxation based on physical verification (Vázquez-Caro and Bird 2010). That in turn helps explain a paradox. On the one hand, historically-minded observers tend to associate taxation with revolt and rebellion (e.g. numberless peasant revolts, the English Civil War in the sixteenth century, the French Revolution, the Boston Tea Party, resistance to colonial hut and head taxes in Africa, etc.). On the other hand, contemporary governments extract much higher proportions of their citizens' income in taxes than did their historical predecessors while facing miniscule risks of violent tax revolts. One reason is that, in high tax countries, taxpayers usually obtain visible returns from their tax contributions, notably in terms of social services and social transfers of various kinds. Another is that most accounts-based taxation is less visible and inflammatory than taxation based on physical verification. It is associated with:

- The extensive use of 'tax practitioners' (variously: lawyers, accountants, fixers) to prepare and present taxpayers' accounts to tax collectors. This reduces the direct face-to-face interaction between taxpayers and tax collectors - visits by tax collectors to shops, offices, warehouses, fields and homes - that is characteristic of physical verification systems. The immediate effect of face-to-face interaction is an increase in the opportunities and incentives for both sides to engage in corrupt deals at the expense of the public treasury. ${ }^{21}$ The longer term effects include less efficient revenue collection and the de-legitimisation of tax agencies.

- The widespread use of withholding, which can be defined colloquially as a process to enable tax collectors to get their hands on tax money that is due before it reaches the pocket of the agent formally liable to pay it. Private sector agents withhold some proportion of the money they would normally transfer to another private agent, and instead remit it to the tax agency as an advance, pre-emptive tax contribution. Banks deduct withholding taxes from the interest they pay their depositors. Incorporated companies do the same for dividend payments. Under PAYE schemes for personal income taxes and social security payments, employers withhold from employees' pay cheques. $^{22}$ The practice of withholding is central to the capacity to levy high tax takes. It is very much easier to persuade taxpayers to part with money that they have not yet received than to extract it from their pockets once it is lodged there.

- More generally, the routinisation of information transfer and of tax payments, that they can be spread over the year and triggered according to a pre-determined schedule.

Relative to physical verification systems, accounts-based tax systems routinise the tax process, stimulate less direct engagement between taxpayer and tax collector, create fewer points of conflict, irritate and mobilise the taxpayer less, and reduce collection costs for the tax agency. ${ }^{23}$ The core objective of contemporary tax administration reform is to intensify these characteristics, making tax collection more routine, more dependent on digital

21 This is a standard assumption made in much economic analysis of taxation, and is accepted by tax administration specialists. For recent evidence, see Imam and Jacobs (2007).

22 In a functionally similar way, larger companies serve as agents for the collection of VAT.

23 The case of property taxes helps illustrate this conclusion. Even in high income countries where taxation is largely accounts-based, property taxes lack the emollient characteristics of most other taxes. There are no intermediaries between the taxpayer and the tax collector, which is typically a very visible local presence - a local council. The assessments of individual properties are typically done by assessors, in personal visits. Re-valuations are done sporadically, and inevitably are accompanied by negative publicity. It is partly for these reasons that property taxes are greatly under-used (Section 8). 
processes, and more predictable (Section 7). In modern tax systems, taxpayers experience personal interaction, if at all, with a range of functionally-specialised staff (assessors, helpline personnel, customer advisers, collectors, debt collectors), rather than the dominant single figure of the local Tax Inspector who, in some low income countries, still does the assessments, collects the money, handles the grievances, gives the advice, and generally monopolises the relationship of individual taxpayers to the collection agency.

\subsection{The effects of international trade}

It is clear why a high ratio of imports and exports should lead to a high tax take. International trade is the classic, core, default source of state income. Historically, rulers have found it relatively easy, both politically and organisationally, to raise much of their revenue at their borders. Governments that find it difficult to collect revenue continue to depend relatively heavily on this default source - although it is often very inefficient because a high proportion of taxes collected at the border may not end up in the public treasury (Section 2). Despite major reductions in trade tariffs in recent decades, governments of low income countries still depend relatively heavily for revenues on taxes on international trade, especially on imports (Table 1).

While econometric studies consistently find that the ratio of international trade to GDP helps determine the overall tax take, the results are not very consistent among different studies: the magnitudes of the causal effects are quite variable, and the ratio of exports to GDP is sometimes not associated with the size of the tax take in a statistically significant way. There appear to be two broad reasons. One is that the underlying statistical relationships - the values of the coefficients in econometric estimations - have changed in recent decades as a result of trade and tax policy reforms in low income countries in particular. Especially in the 1960s, 1970s and 1980s, many governments imposed heavy taxes on exports of agricultural commodities like cocoa, coffee, cotton, groundnuts, rubber, sisal, sugar and tea (Bates 1977). In more recent decades, those taxes have mostly been lifted (Bezemer and Headey 2008). Similarly, since the 1980s, most low and middle income countries have reduced trade tariffs, sometimes radically. ${ }^{24}$

The other broad reason for the inconsistency of the econometric results is that the data on international trade and revenues from it has become less reliable in one major respect. Since around 2000 , the global prices of commodities, especially mining and energy commodities (oil and gas), have increased considerably. Low income countries have become relatively more important sources of these commodities. But transnational companies seeking to minimise their taxes have increasingly been using accounting practices that change the recorded location of their activities, exports, imports, incomes and profits. This is especially the case with mining products, and with mining activities in low income countries (Lundstøl et al. 2012). The extent to which these commodity exports are actually taxed and the accuracy of both the export and the revenue figures would all affect econometric estimations of the relations between export ratios and tax takes. ${ }^{25}$

The interim conclusion is that, while higher ratios of international trade to GNP boost the tax take, it is hard to calculate that effect with any precision for contemporary low income

\footnotetext{
$24 \quad$ In many cases, VAT was introduced more or less simultaneously. Lower income countries in particular often found that enhanced VAT revenue did not fully compensate for lost tariff revenue, probably in large part because they often introduced rather 'truncated' or incomplete VAT systems that both included many exemptions and failed to create the incentives for the 'matching' of invoices in business-to-business transactions that lies at the heart of the capacity of welldesigned and well-managed VAT systems to reduce tax evasion (Baunsgaard and Keen 2005).

25 Another result of the tax avoidance strategies used by transnational companies is that the intangible services that constitute a growing proportion of international trade (intellectual property rights, internet-based transactions) are also often badly measured at the level of individual country. This too may complicate the statistical estimation of the effect of international trade ratios on the tax take. At present, the magnitudes of such transactions are tiny in most low income economies.
} 
countries. And that in turn reduces our ability to produce more precise quantitative estimates of the impact on the tax take of the other important set of variables relating to the structure of national economies: income levels and sectoral composition of the economy.

\subsection{Economic structure and the tax take; conclusion}

The tax take is broadly proportional to national income levels in large part because, in higher income (and urbanised, non-agricultural) countries, it is much easier for tax agencies to tap into revenue sources without incurring high collection costs or generating adverse political reactions. It is important to emphasise this relationship because of the frequency with which observers assume or assert that it is primarily because of politics or policy that tax takes in low income countries (or in Africa, Latin America, etc.) do not come close to the levels of 3045 per cent found in most OECD countries (Table 1). It makes no sense for low income countries to aim to match OECD tax take levels.

However, it is equally important to insist that the statistical relationship between economic structure and the tax take is not in any strong sense of the term 'determinant'. Countries with similar incomes and economic structures can have very different tax takes. In some cases, other historical or structural factors play a role. For example, differing modes of colonial exploitation of the economies of Africa are still (statistically) detectable today in variations among African countries in the total tax take (Mkandawire 2010). But we really do not know the relative importance of these various structural factors, and how far they affect contemporary efforts to increase the tax take.

Three practical conclusions emerge:

- Do not use the size of the tax take as an indicator of how effectively governments are tapping into their tax base, either cross-sectionally or over time. The concept of 'tax effort' is more useful. The most common method of calculating 'tax effort' involves starting with a statistical estimate of what one would expect the tax take of any given country to be in the light of its economic structure. 'Tax effort' is then estimated as the difference between that predicted tax take and the actual tax take. ${ }^{26}$

- However, estimates of tax effort made in this way - from residuals in equations whose coefficients tend to vary from one data set to another - cannot be very precise. Further, these estimates may be of little help to policymakers seeking a realistic estimate of how much tax might reasonably be collected in any specific country. ${ }^{27}$

- There is no reason to believe that economic structure - or other structural and historical factors - so tightly determine tax takes that arguments for improving tax policy and tax administration are in any way weakened. There is scope to improve revenue performance in every country.

\section{The use of the tax system for rent-taking}

There is a large and impressive body of social and historical theory that explores the relationships between government, taxation and patterns of political and economic development. ${ }^{28}$ The major authors have mostly presented taxation as a political game involving two main categories of actors: political executives ('rulers') and (various categories

\footnotetext{
26 See for example IMF (2011: 59-62). The estimates there relating to 36 low and lower-middle income countries over the period 1991-2006 show that the tax effort varied between 41 per cent (Bangladesh) and 96 per cent (Côte d'Ivoire).

For guidance on that issue, see Cyan et al. (2013).

See for example Chaudhry (1997); Dincecco (2011); Levi (1988); Mann (1993); Tilly (1992); Yun Casalilla and O'Brien (2012).
} 
of) taxpayers. That simplification is often adequate for the purposes of 'big history'. But it can be very misleading when the objective is to understand the obstacles to raising tax revenues in low income countries today (Moore forthcoming). The tax collection process involves a wider range of significant actors. It is better to start from the assumption that there are at least four main categories of actors and interests, each of them internally differentiated: taxpayers, tax intermediaries, governments (i.e. central political executives) and revenue collection organisations.

Tax intermediaries are important and numerous in low income countries. They include tax lawyers; accountants; clearing agents, forwarding agents, brokers and managers of bonded warehouses (for Customs); formal associations of any of these professions; support staff employed directly and unofficially by official tax collectors; and the many taxpaying organisations authorised and required to collect tax from others and pass it to formal tax agencies (Section 1). ${ }^{29}$ In Nigeria at least, a considerable fraction of the business of formal tax collection, especially at the sub-national level, is in practice sub-contracted to people who would historically have been labelled 'tax farmers' (Omoigui Okauru 2013). I do not in this paper explore the roles played by these tax intermediaries. Here I focus rather on the ambiguities associated with formal tax collection agencies. We cannot assume that they are the agents of the political executive or the public treasury, accustomed to following the instructions given from above and collecting money solely for transfer to the treasury. It is of course true that no organisation is ever 100 per cent the agent of the organisation that is formally its principal. The subordinate agent always has a little scope to determine its own agenda and to hide relevant information from its principal. But, in the case of some tax agencies in low income countries, the degree of divergence from a principal-agent relationship seems substantial. ${ }^{30}$ First, tax collection agencies collect revenue not only for the public treasury, but also for a range of other actors: their own staff; their political masters; and tax intermediaries. Second, and largely because of the extent to which they provide continuous 'informal' funding for their political masters, their relationship to their formal principals typically ministers of finance, sometimes prime ministers or presidents - may be more complex and less hierarchical than is implied in the formal organisation chart.

These rent-taking activities, and the partial political autonomy that this generates for revenue collection agents, are dependent on the capacity of revenue collection agencies to raise more money from taxpayers than appears in the official records. ${ }^{31}$ Stories about corrupt tax officials are as old as tax collection itself. Today it is widely believed that the (Customs) organisations that collect taxes at international borders are better placed to extract rents than other tax agencies. In many low income countries at least, there is visibly more money around the staff and offices of Customs agencies than of 'internal' tax authorities. ${ }^{32}$

\footnotetext{
29 Cantens' (2012, footnote 5) figures for 2010 suggest that, relative to the volume of cargo handled, Customs intermediaries were about 22-26 times as numerous in the ports of Abidjan (Côte d'Ivoire) and Douala (Cameroon) as in Le Havre (France).

30 I say 'seems' because we have no conclusive evidence, and have to rely on a mixture of fragmentary pieces of research and the unattributable information from insiders.

31 In using the term 'autonomy', I am referring to actual political relationships, and not to the formal, legal autonomy granted to so-called 'autonomous' or 'semi-autonomous' revenue agencies. These may have little real autonomy (Fjeldstad and Moore 2009).

32 This situation is likely to change, and to a limited degree is already changing in low income countries. On the one hand some countries are taking advantage of digital technologies to introduce 'preferred trader' schemes that permit trusted importers and exporters to declare and clear all their shipments in advance and pass through border points without any routine physical checks. On the other hand, the dominant source of tax rent-taking and fraud in higher income countries is now 'carousel schemes' that essentially involve false trade documentation to make false claims for VAT refunds on exports. These schemes require only limited cooperation from within revenue agencies, at the back-office level rather than at border posts. Such frauds are likely to become more common in low income countries if they continue to introduce increasingly 'textbook' implementation procedures into their (generally simplified) VAT systems, notably by increasing their willingness actually to remit VAT payments to exporters.
} 
How does rent-taking work in practice? A number of pieces of recent detailed and often quantitative anthropological and survey research collectively throw significant analytical light on these processes, especially in respect of Customs..$^{33}$ The following findings recur:

(1) Almost all illegal payments to Customs staff are made by intermediaries on behalf of their clients.

(2) Relationships between intermediaries and Customs staff are to a significant degree driven by incentives on both sides to minimise the potential adverse effects on the flow of business of the high degree of friction and conflict that is intrinsic to the operation. While Customs staff have the power to inflict very high costs on 'noncooperative' customers by detaining or confiscating goods, or by exercising discretion about classifications and valuation, they also need, on pain of various kinds of administrative punishment, to keep business running smoothly in order to meet their regular revenue collection targets.

(3) There are corresponding pressures for all parties to reach understandings - possibly independently of formal procedures and policies - and to assist one another where possible. For example, individual Customs officers or units might rely on their larger customers to pay dues very quickly - or even in advance - in order that they do not fall behind their schedule in remitting collections to the public treasury.

(4) There are high levels of informal organisation on both sides. Networks of Customs officers, in which power and authority do not always accord to the formal hierarchy, organise the flow of collective informal earnings, both internally and externally to powerful politicians. Associations of intermediaries might receive some of these informal earnings to meet their collective expenses.

(5) While there exist collective mechanisms to regulate the collection and redistribution of informal earnings, these are neither comprehensive nor fully transparent to all participants. Individual Customs officers may also collect on a personal basis. Because of incomplete information and competition over informal earnings, conflicts may erupt periodically.

(6) Moving staff between posts with different potentials for informal earnings is a major mechanism for the internal exercise of authority.

(7) Different border posts within the same country are often in competition with one another for business. They try to attract traders with combinations of lower charges, predictability, and efficient service.

(8) On land border posts in particular, Customs agencies may both compete and cooperate with one or more other state institutions (the military, environmental or health regulation agencies) to collect money from traders.

(9) These various collection agencies may routinely use local non-state agents - criminal gangs, taxi drivers - to obtain information on attempts to bypass border posts, and to punish offenders.

We have no hard information on the extent to which revenue agencies aggregate and transfer funds informally and illegally to their political masters. These flows seem to be quantitatively and politically significant in many low income countries. This in turn probably helps explain why it is often so difficult to reform tax collection agencies to improve their performance. Especially in that minority of tax agencies that have made very little use of digital technologies and in which revenue is raised through close personal interactions between individual staff members and individual taxpayers, any kind of reform can appear threatening, to individual officers and to the complex flows of illegal rents in which they participate. Staff collectively have a high capacity to resist reform. Governments need money continuously. This is especially true for the governments of poorer countries, which find it difficult to borrow money

Amin and Hoppe (2013); Bilangna and Djeuwo (2013); Cantens (2012); Cuvelier and Mumbunda (2013); Titeca (2009); Titeca and Kimanuka (2012). There is less research material on corruption in 'internal' tax collection. For an example, see Fjeldstad (2007). 
commercially in a flexible fashion. The potential revenue and economic costs to government of whispered 'tax collection strikes' are very high. The richness of tax collectors' informal knowledge and networks makes them irreplaceable outside situations of extreme crisis. The iconic cases of radical reform of tax administration in poor countries in recent decades notably Peru in the early 1990s (Durand 2002), Uganda in the later 1990s and early in the 2000s (Therkildsen 2004), and Rwanda over a similar period (Land 2004) happened when state power was effectively reconstituted after near-collapse, including the breakdown of revenue collection. The tax collectors had already lost their bargaining power.

It seems obvious that rent-taking of the kind sketched out above reduces tax takes, in two ways. Directly, money that is legally scheduled for the public treasury goes instead into the hands of tax collectors, tax intermediaries, politicians and taxpayers. The volumes may be large. Recent World Bank research in West Africa suggests that recorded cross-border trade might be a small fraction of actual trade and that, while unofficial payments made at borders and frequent road blocks account for a high proportion of road transport costs, they may still often amount to less than the Customs duties that should in principle be levied. ${ }^{34}$ Indirectly, the inevitable popular perception that tax collection is corrupt will tend to undermine any efforts made to persuade citizens that paying their taxes is either a civic duty or a means of enhancing collective welfare. 'Tax morale' and the extent of quasi-voluntary compliance remain low (Cummings et al. 2005; Torgler 2004, 2005).

Whether direct assaults on 'corruption' within tax agencies are the best means of increasing revenue collection is beyond the scope of this paper. There is no good evidence on this. It is however hard to think of a recent case where anti-corruption measures alone - as opposed to the body of technological and organisational reforms in which they can be embedded have made a significant contribution to raising the tax take. ${ }^{35}$

\section{The use of the tax system as a direct instrument of rule}

If raising formal revenues were the dominant motivation for governments to establish and maintain tax systems, how could we explain the extent to which, even in low income countries where governments find it hard to raise revenues, they routinely give away a third or more of their potential annual tax income by granting large numbers of tax exemptions or tax holidays of various kinds $?^{36}$ The broad answer to that question is that tax agencies, like most public institutions, rarely serve a single purpose. They attract a range of actors who try to colonise or influence them for specific purposes. That is especially true of tax agencies

$34 \quad$ Amin and Hoppe (2013). See also Cantens et al. (2013); Cuvelier and Mumbunda (2013); and Titeca and Kimanuka (2012). Transparency International does annual surveys of the experiences of the population of the East African Community countries of being asked for and paying bribes to specific organisations. In 2011, 115 organisations were listed. The Burundi Revenue Authority ranked $3^{\text {rd }}$ highest in overall corruption levels; the Uganda Revenue Authority $5^{\text {th }}$; the Tanzania Revenue Authority $33^{\text {rd }}$; and the Kenya Revenue Authority $58^{\text {th }}$. In Rwanda, reported corruption was so low that it was statistically invisible (Transparency International 2012: 1-3). These figures may be cited as evidence either that corruption events are widespread in the tax field or very variable among countries.

35 For an interesting recent insight into how Customs may be reformed to reduce corruption, see Rabelland and Rajaram (2013). Note also that the increasing scope for experienced tax administrators from low income countries to work internationally at international salaries (Moore 2013) provides incentives for some of them to become recognised reformers.

36 The calculation of the extent of tax exemptions is challenging, both conceptually and practically. There is no single agreed method. Most estimates are approximate, and many are informal and/or confidential to tax authorities. In a recent publication, the OECD chose to cite figures from recent estimates of the volume of tax exemptions in six African countries (OECD 2013b: 10). I assume these are from more reliable sources. On average, tax exemptions amounted to 33 per cent of tax revenue collected (the range was 12.5 per cent to 60 per cent), and to 5.5 per cent of GDP (range 3.4 per cent to 10 per cent). Some tax specialists fear that exemptions are becoming more rather than less common. 
and of the policing agencies that they broadly resemble. The wide powers that tax agencies enjoy to raise money from the public enables the people who control them to use those powers selectively to favour some people and companies, through tax exemptions, and to disadvantage or threaten others, through punitive tax audits. In polities in which there are inadequate mechanisms to restrain or hold to account the political executive (i.e. the core power holders: ministers of finance, prime ministers, cabinets, presidents, etc.), tax systems may be used in these ways not just to raise the resources needed to enable governments to rule, but as direct instruments of rule in their own right.

Taking a scholastic perspective, 'tax exemption' could be defined very broadly, to cover every case in which the notion of 'equal treatment' could be considered violated by the failure to tax some activity. For example, very small business enterprises with a turnover below an annual threshold are exempted from some taxes in most countries for pragmatic reasons: the costs of trying to tax them are likely to eat up all or most of the revenue extracted. A purist might consider this to be a tax exemption. But that scholastic approach makes it virtually impossible to calculate the levels of exemptions in any country, and is of no practical value. The practical touchstone for deciding whether some provision should be counted as a tax exemption has to be whether the activity sensibly and reasonably could be taxed, with the implication that it has been exempted for a specific reason. In practice, most of the exemptions with which we are concerned are visibly discretionary. They are in principle granted to specified activities (e.g. income attributable to owned patents; leasing finance; new investments in sailboat manufacturing; imports of high grade fuel oil) but in practice are granted mainly to individual companies, to narrowly-defined industrial sectors, or to companies located in a specific geographical area (e.g. an export processing zone). Exemptions can take a variety of legal forms, including time-bound tax holidays, accelerated depreciation allowances, and permanent exemptions from particular taxes. They may cover one tax, several taxes, or all taxes. They may be granted by a single agency within government (the revenue authority, the ministry of finance, the ministry of industries, the investment promotion board) or by several. There may be clear criteria and procedures for granting exemptions, or none except the word of the president. The beneficiaries may or may not be required to register with the revenue authority and file returns so that their compliance can be monitored and revenue from nonexempt activities collected.

There is a debate in principle about the desirability of tax exemptions of any kind. ${ }^{37}$ Supporters argue that governments should have the power to use tax exemptions to encourage certain kinds of economic activities and investments. Critics argue either that it is undesirable in principle for governments to try to shape market decisions in this way or that governments cannot be trusted to use this power appropriately. The facts about tax exemptions in low income countries, contested and fragmented as they are, give a great deal of support to the latter position. If governments were granting tax exemptions purely in the pursuit of economic growth and innovation, ${ }^{38}$ they would be consistently following a number of practices, including:

- Giving exemptions only on the basis of clear criteria and agreed, transparent and contestable procedures

- Placing time limits on all exemptions

- Monitoring their use and outcomes

- Ensuring that all exemptions and investors were registered with the revenue authority, so that the enterprise could be taxed after the expiry of exemptions. 
The fact that these practices are far from standard in low income countries supports the view that a major motivation is political. ${ }^{39}$ Research strongly and repeatedly reinforces the argument that, however desirable some tax exemptions or incentives might be in principle, current levels are unjustified and procedures for granting them require major reform. ${ }^{40}$ Few political scientists have investigated the political rationale for exemptions in a consistent fashion. We mostly have to guess the extent to which they are granted in exchange for broad political support, party and political funding, or simple bribes. A recent paper by Ole Therkildsen (2012) constitutes an interesting exception. He finds that a major driver of the spread of tax exemptions in Tanzania is increasing group competition within the ruling CCM party, and thus an ever-widening trawl for political finance to fund that competition. Business offers political financing in return for tax exemptions. ${ }^{41}$

The power to tax - and therefore the power to grant tax exemptions - is not just a means of raising financial resources for the state. It is also - and especially in polities characterised by low levels of democratic institutionalisation and legitimacy - a basic and direct instrument of rule. It can be used as both carrot and stick: to generate support and to discourage oppositional activity. On the one side, the threat of a special tax audit is a coercive means of aligning wealth to power. Actual or potential political opponents of the government, or even companies and individuals that are unwilling to provide financial support to the people in power can be intimidated by the threat or fact of an audit. This is often a powerful political signal. ${ }^{42}$ On the other side, tax exemptions are a widespread means of generating financial contributions and other influential support for individual politicians and political parties. ${ }^{43}$ To the extent that this analysis of the political motivations for tax exemptions is correct, the prospects for reducing their incidence in low income countries seems limited. The battle is however worth fighting, for they are a significant cause of low revenue collections and of the de-legitimation of tax systems generally.

\section{The influence of interest group politics}

There is no doubt that, through their direct and indirect engagement in political activity, socioeconomic interest groups exercise a large and continuous influence on tax policy and tax administration in virtually all political jurisdictions. Any other conclusion would be surprising, because it would violate our understanding that humans are intrinsically political animals. Taxes are involuntary contributions to government income, extracted to some degree through coercion, and unmatched by specific promises or contracts about the uses to which they will be put. Just as both small and large taxpayers engage, if they can, in individual or small-group bargaining with tax collectors and governments to reduce their payments below the formal norm (Section 2), they also engage in more collective politics to influence both the distribution of the tax burden and the (related) patterns of public spending and borrowing. Most political science literature on taxation deals mainly with distributional issues: i.e. interest group political competition over the distribution of the taxing burden and the spending benefits. The broad patterns of taxation politics are relatively predictable:

\footnotetext{
39 I am very indebted to the verbal address on these issues delivered by Richard Bird to the Annual Meeting of the International Centre for Tax and Development in Cape Town on 13 December 2012.

$40 \quad$ James (2010); Klemm (2009); Klemm and Parys (2012); Li (2006); and Zee et al. (2002).

41 This raises the question of whether the widening of electoral competition in sub-Saharan Africa helps explain the apparent increase in the frequency of tax exemptions.

42 For example, after the former Youth League leader Justin Malema was expelled from the ruling African National Congress in South Africa in 2012, he was found to owe 16 million rand to the South African Revenue Authority.

Similarly, Pierre Englebert (2009: 72-4) argues that one of the instruments used by national political authorities in Africa to purchase a degree of tactical loyalty to the regime on the part of potentially separatist local elites is to hand them unregulated local taxing powers. Those powers are often employed arbitrarily and coercively to extract rents for the groups that control local government (Fjeldstad and Therkildsen 2008; Prud'homme 1992).
} 
- Material interests play a major role in the establishment of political alignments. For example, companies will tend to prefer that additional revenue should be raised through increased VAT rates, which are borne by consumers, and not through additional corporate income taxes.

- Because of the legal and accounting complexities of taxing, budgeting and public spending processes, there is considerable scope for politicians to choose the ways in which taxation and fiscal policy issues are framed, and for information to be misrepresented in political debate. ${ }^{44}$

- The institutional arrangements through which fiscal decisions are made sometimes have a significant impact on fiscal politics and outcomes (see Section 5).

Tax is very political. We can be sure that interest group competition has a great influence on the distribution of tax burdens. But does it also affect the aggregate tax take in any consistent way? We have no confident answer to this question. ${ }^{45}$ I suggest and then explain two tentative conclusions, both related to the ways in which the degree of income or wealth inequality might affect the tax take indirectly through its influence on interest group politics:

- High levels of income or wealth inequality within a country probably tend to reduce overall taxation levels.

- Effective 'fiscal contracting' - the exchange of revenue contributions from specific, differentiated taxpayer groups for preferred spending patterns on the part of government - is more likely if income is more equally distributed.

\subsection{The effects of high inequality on the tax take}

Political economy theorists who rely more on deduction from abstract principles than from empirical observation have argued that higher levels of income or wealth inequality within a democratic country tend to increase overall taxation levels (Corbacho et al. 2013: chapter 2). The logic is that the higher the degree of inequality, the larger the proportion of voters who can expect, without facing higher tax bills themselves, to benefit from higher taxation on the rich and subsequent increased public spending. The historical experience of Latin America has long constituted a challenge to that expectation. It has long been characterised by high degrees of inequality and low tax takes, with little evidence that episodes of democracy wrought any appreciable change. In 1976 Michael Best (1976) published a classic article on the subject that presents a set of arguments that, while quite general and incomplete in detail, seem broadly accurate at the level of broad-brush historical interpretation. The core schematic elements of the argument are:46

- Latin American economic elites had little general interest in high public spending, and would support it only in contexts where they clearly stood to gain, including some military spending and, more commonly, high subsidies for public universities, that largely catered to their own children. They would otherwise purchase their own health and education services - and some policing - rather than risk having to meet the cost of broad public provision of these services.

- While electoral verdicts on these issues often went against them, they would, even in democracies, be able to ensure - through legislation, through apparently obscure constitutional provisions, through their influence over the judiciary, and through their governance institutions that separated tax policy decisions from public spending decisions (Section 5) - that (a) the tax burden was skewed toward consumption taxes and thus onto the poor, and (b) the overall tax take remained low. 
It is very hard to test statistically the effects of income and wealth inequality on the national tax. There are many obstacles to the creation of the kind of panel data set that would be needed, including the challenges of estimating the division of the tax burden among income or wealth groups. It is again in relation to Latin America that we are most likely to see progress. The fiscal data is more reliable and standardised than for most of Africa and low income Asia, and currently considerable efforts are going into improving the data, estimating the incidence of the tax burden among income groups, and generally trying better to understand the politics of taxation. ${ }^{47}$

Subject to any conclusions that emerge from further research in Latin America or elsewhere, it seems sensible to assume that, for the kinds of reasons given above, income and wealth inequality are more likely to be associated with low than with high tax takes.

\subsection{Fiscal contracting}

Progressive Latin American intellectuals, especially those associated with the UN Economic Commission for Latin America and the Caribbean in Santiago, have long been attracted to notions of social and fiscal contracts or pacts. Leaving aside the explicit fiscal pact that the political parties and a number of interest groups signed in Chile in 1990 just before the restoration of democracy after Pinochet's military rule (Boylan 1996), the discourses around fiscal/social contracts are in most cases best understood as pleas to the Latin American rich that they should pay more taxes in order that governments can engage in more social spending and thus strengthen 'social solidarity'. Thus used, the concept has considerable normative appeal but little analytic substance. However, a few years ago Jeffrey Timmons (2005) presented an analytic notion of the fiscal contract, and his work has recently been extended, for Latin America, by Bird and Zolt (2013).

The core assumptions behind Timmons' approach are that:

- Governments can be considered as quasi-monopolistic providers of public services.

- From the perspective of their institutional self-interests (in staying in power, expanding authority, etc.), governments are likely to seek and seize opportunities to expand their revenue collections and their spending responsibilities provided that they can broker deals that will command support among potentially competing socioeconomic interest groups (notably various types of taxpayers and various potential beneficiaries of public spending) by acting as 'discriminating monopolists'.

Timmons' main proposition is that governments will seek to achieve the overall fiscal contract - the agreement to tax and spend more - by making different deals with different interest groups. Specifically, by looking at patterns of taxation and public spending across a large sample of countries, Timmons tests the proposition that governments will exchange revenues for policies not with taxpayers en masse, but with specific groups of them. It is groups of taxpayers, not the whole category, that provide revenue for the state, through distinct channels, for the services that they specifically need. In sum, using two data series, Timmons finds first that governments that spend high proportions of GDP on social services like health and education tend to depend relatively heavily for their incomes on regressive consumption taxes - notably sales and excise taxes, and VAT - that fall relatively heavily on the main beneficiaries of this kind of spending, i.e. the poor. Because government is providing services for the poor, it is also able to tax them. Simultaneously, those governments that spend a high proportion of GDP on protecting property rights - i.e. on the services especially valued by wealthy people - also depend relatively heavily on taxes that bear most heavily on the rich:

Among the many sources, see Arnson et al. (2012); Bird and Zolt (2013); Corbacho et al. (2013); and Lopez-Calva and Lustig (2010). 
taxes on income and wealth. Some governments focus their taxing and spending more on the poor, some on the rich, and some on both.

The conclusions of any single set of econometric estimates are always vulnerable to modification or refutation as a result of re-estimations using more data, better data, or improved estimation methods. We cannot yet assume that fiscal contracting, as Timmons defines it, actually takes place on any scale. However, his framework provides an analytical advance - with potential policy relevance over the standard near-truism that taxpayers are more willing to pay taxes if they feel they are getting something in return. Bird and Zolt (2013) have used the fiscal contracting notion recently in the effort to make sense of exciting recent fiscal and socio-economic developments in much of Latin America, including: (a) reduced levels of income inequality; (b) the steady growth of tax takes; and (c) the inception of substantial programmes for social transfers to poor people, including through conditional cash transfer schemes. Bird and Zolt hypothesise that a period of sustained economic growth, leading to the expansion of what is often termed the new middle class, is changing the Latin American fiscal politics I summarised earlier, notably the lack of interest of actual/potential income tax payers in financing public service expansion. They suggest that the new middle class are both in a position to pay personal income taxes and interested in using expanded public services, including health and education. Bird and Zolt suggest that this could be the beginning of a substantial change in the fiscal politics of Latin America: a new fiscal contracting process in which large non-poor populations are increasingly willing to pay taxes, including direct income taxes, in return for expanded, relatively universal public services. ${ }^{48}$ If that is correct, then parts of Latin America may be on a convergence path with the classic European welfare states: relatively high levels of publicly-funded, universal social protection funded by taxes that impinge substantially on median earners as well as the rich.

The analysis by Bird and Zolt implies a specific hypothesis: fiscal contracting - the exchange of revenue contributions from specific, differentiated taxpayer groups for preferred spending patterns on the part of government - is more likely if income is more equally distributed. But more important perhaps is the approach itself. The analytics of the fiscal contracting framework have not yet been explored or tested in detail. It does however seem to provide a way of developing nuanced and testable hypotheses about the causal connections between levels of revenue collection and the fiscal politics of interest groups.

\section{The configuration of governing institutions}

It is more than two decades since Steinmo (1989) produced one of the classic illustrations of how variations in institutions visibly shape public policy: an explanation of how the configuration of governance institutions helped explain why the tax take - and the general level of political support for taxation - was lower in the United States than in most countries of Western Europe. It is essentially a matter of the extent of fusion within a single institution of the power to raise revenues and the power to decide on the allocation of public spending. Assume that decisions to raise revenue are always to some degree unpopular. Politicians will tend to avoid them if they can. However, in European parliamentary democracies, both taxing and spending decisions are made by the political executive, controlled by a single political party or by a party coalition. When fiscal decisions are fused in this way, the unpopularity that arises from increasing taxes can be (more or less) offset by the popularity that can arise from the resultant increased public spending. By contrast, in the government of the United States, fiscal initiatives and decisions are located to a much higher degree in

\footnotetext{
48 They also suggest that the United States might be undergoing the reverse process: the decreasing willingness of the people who pay most federal tax - relatively wealthy payers of personal income tax - to finance public services from which they receive little direct benefit.
} 
committees within the legislature (Houses of Representatives and Senate). The membership of revenue-raising and spending committees differs. The members of revenue-raising committees suffer unpopularity when they raise taxes, but do not benefit from any of the popularity that might be generated by increased spending. They are motivated to be especially resistant to increasing taxes. There is, Steinmo argued, an inbuilt bias against revenue raising in American political institutions, at least when compared to Western Europe.

These ideas about the impact of political institutions on tax levels can be tested only through comparisons. Testing general propositions requires reliable fiscal information for a substantial period of time on a relatively large sample of countries (or other political jurisdictions) that are similar in many respects but exhibit variation in the political institutions that are believed to affect fiscal outcomes. Within the low income regions of the world, only Latin America meets these conditions. It has a diverse mixture of presidential systems, in which powers over fiscal issues tend to be relatively dispersed, and parliamentary systems, in which fiscal authority is more concentrated. But there are variations within each system. Researchers have ranked Latin American polities according to the power of the political executive relative to the legislature in respect of fiscal decisions. They have then reached conclusions analogous to Steinmo's: when power is more concentrated within the political executive, the tax take tends to be higher (Corbacho et al. 2013: 27-29).

Other variations in governance institutions also seem to affect the tax take. If electoral systems over-represent rural populations, who typically provide less revenue per head than urban populations (Section 1), then the tax take seems to drop fractionally (Ardanaz and Scartascini 2011). The quality and temporal coverage of fiscal data in low income countries is however sufficiently low that we need to be: (a) wary of statistical findings that are not replicated with differing data sets, alternative definitions of key concepts and varying statistical models; and (b) pessimistic about the likelihood that cross-national statistical analysis will within the next few years throw much new light on the political variables that affect tax takes.

\section{The difficulties of taxing transnational transactions}

There is now a wide international consensus, expressed in particular in the decisions of the 2013 meetings of the G8 and the G20, that the current system of taxing international economic transactions is in need of substantial reform. There are a variety of interpretations of the problems and the potential solutions, but little doubt that the core problem lies in the tension between:

- The fact that taxation is still dominantly the responsibility of national governments, who compete actively with one another - through in various ways reducing effective tax rates - to obtain larger shares of taxable activities, including by encouraging the formal relocation of 'taxable activities' through accounting and legal fictions of various kinds.

- The steady growth over recent decades in the relative importance of transnational economic activities, with a resultant increase in the incentives and scope to engage in these accounting and legal fictions.

The main problem to date is not so much that corporations as a whole have avoided taxes. The contributions of corporate taxes to government revenue have on the whole held up. It is rather that the current system is: 
- Economically inefficient, because (a) actual tax burdens are allocated with a high degree of arbitrariness, and with a general bias against economic transactions and companies that are not transnational, and (b) considerable resources are consumed in gaming the system.

- Potentially politically unsustainable, especially in those OECD countries facing major fiscal constraints and reductions in public spending.

- Unnecessarily complicated because transnational corporations, that integrate their activities globally - in terms of the location of activities, value chains, financial and management systems, research and development, etc. - are still taxed as if they in reality comprised simply a large number of independent companies incorporated (i.e. legally domiciled) in a variety of jurisdictions. ${ }^{49}$

- Least effective in producing reasonable and sustainable outcomes in respect of the fastest-growing categories of international economic transactions: 'intangibles' (products of service industries) rather than 'tangibles' (products of manufacturing, agricultural or extractive industries); and, within the intangibles category, various kinds of e-commerce activities.

It is difficult to say whether the problems of the current system are worse in:

- High income countries, where transnational corporations focus their activities and where there is much greater scope for tax avoidance and evasion because of the higher proportion of transnational economic transactions that involve 'intangibles' (services like management, design, intellectual property rights) and e-commerce.

- Low income countries - and especially smaller low income countries - where tax administrations tend to be relatively weak and under-equipped, and find it difficult to challenge effectively the accounts presented to them by larger transnational companies (Introduction).

The biggest single cause of low tax takes in many low income countries is low taxation of the extractive industries to which they are often hosts. This is especially true of mining activities, which are more likely than oil and gas extraction to be entirely in the hands of overseas private transnational companies, and are generally much more severely under-taxed than oil and gas (IMF 2012). To some degree, reforms to improve the taxation of extractives, especially mining, can be undertaken separately from the more general reforms to improve the international tax system that have been suggested by G8 and G20. These are however complex issues, for which the appropriate solutions are probably different for different low income countries (Lundstøl et al. 2012).

The most widespread form of revenue loss for developing countries from transnational economic transactions is almost certainly transfer mispricing: accounting for the value of imports or exports in ways that make possible the concentration of company profits in low tax jurisdictions or tax havens. Transfer mispricing dominantly takes place between the affiliates and subsidiaries of large transnational corporations. It is clear that it is practised on a substantial scale, ${ }^{50}$ although all estimates of the global volumes are contestable. It is however only very recently that serious analytical and political attention has been paid to the issue. Tax authorities worldwide are tending now to take a tougher attitude to transfer mispricing, and are trying, with some success, to curb the worst abuses (Ernst and Young 2013). The optimists argue that more sustained attention to the issue might lead to significant additional revenues, even for poor countries with relatively weak tax administrations. Pessimists believe that

\footnotetext{
49 There is a strong logical appeal of the notion of taxing transnational corporations as a single global entity, through what is termed unitary taxation or formulary apportionment - <http://www.ictd.ac/en/world-upside-down-new-approachinternational-tax>. However, this proposal faces many practical problems.

$50 \quad$ Fuest and Riedel (2012); Leite (2012); Nitsch (2012); OECD (2013a).
} 
transnational corporations, equipped with hordes of very highly paid specialist accountants and lawyers, will find a way to circumvent every check.

We can be sure that the under-taxation of transnational economic transactions is a significant cause of low tax takes in low income countries. It is far less clear what should be the priorities as far as low income countries are concerned, and how far the current international tax reform agenda - that includes measures to improve the flow of information among national tax authorities - will address the immediate needs of low income countries.

\section{Insufficient use of advanced tax administration practices ${ }^{51}$}

In the latter decades of the last century, a strong consensus emerged among taxation professionals globally that the formal distinction between 'tax policy' and 'tax administration' was of limited policy relevance, because the two domains are in practice highly interdependent. Poor administration can easily undermine well-designed tax policies. The essence of good tax policy is that it can easily be administered. This consensus is typically expressed in the aphorism 'tax administration is tax policy'. This refers in particular to the extent to which complex tax codes and schedules and complex procedures provide wide scope for avoidance and evasion.

The emphasis in tax reform shifted to improvements in tax administration. There has emerged a package of tax administration reforms that have spread widely. Although these innovations have been developed mainly in high income OECD countries, they are broadly appropriate to low income countries - not least because they are in large part driven by the adoption of mainstream, low-cost information and communication technologies. Elements of these reforms have been adopted in virtually all low income countries, sometimes more in rhetoric than in reality. Few specialists have taken the view that they are fundamentally inappropriate to low income countries.

Commentators list and classify these advanced tax administration practices differently. For present purposes, it is useful to group them into three overlapping clusters:

\subsection{Organisation by taxpayer segment and function, not tax type}

The main historical principle for the structuring of tax agencies was tax type. Offices and individuals would be assigned to collect only one of, for example, customs duties and excise, sales or income taxes. While appropriate to very low income economies with limited commercialisation, this practice results in competition among different tax offices to obtain money from the same taxpayers, failure to share information about taxpayers, and high transaction costs for taxpayers who have to deal with two or more tax offices. It also reduces the chances that tax policy will be regularly appraised from a strategic perspective.

Structuring tax collection by tax type is now giving way to two alternative organisational principles. The first is what is known in the trade as taxpayer segment, i.e. type of taxpayer. The application of the principle has mainly involved the concentration of a scarce resource the most competent and committed accountants and auditors - on the complex affairs of the

$51 \quad$ This section derives immediately from Moore (2013). A wide range of sources are cited there. Some of the more current and useful are Bergman (2003); Bird (2004); Bird and Zolt (2008); Cantens et al. (2013); Cantens et al. (2010); Crandal (2010); Ebrill et.al. (2001); Fossat and Bua (2013); Kidd (2010); Kloeden (2011); OECD (2009); Vázquez-Caro and Bird (2010); Zake (2011). 
small number of large companies that typically provide a high proportion of tax revenue for governments of low income countries. ${ }^{52}$ This in turn permits the deployment of staff with weak accounting skills on more routine tasks. ${ }^{53}$ The revenue agencies of most OECD countries now have a separate unit for large taxpayers (OECD 2009: 50). Similar units have been established in more than half the countries of Anglophone Africa, although their effectiveness is quite variable (Kloeden 2011: 27-29).

The second organisational principle that is becoming more widespread is function, with distinct units for activities like taxpayer registration, processing tax returns, processing payments, debt collection, auditing and investigations, finance, personnel, legal affairs and dispute resolution, investigations and internal compliance (anti-corruption). The main benefits of organising by function are those of specialisation (Kidd 2010: 6-7).

As of 2011, only in two small Anglophone African countries (Seychelles and Swaziland) was revenue collection still organised principally by tax type; and only in these and two other cases (Botswana and Zimbabwe) was there no attempt to organise according to taxpayer segments (Kloeden 2011: 24-25). The tax administrations of Francophone Africa have undergone less reform, in this and in other respects (Fossat and Bua 2013).

\subsection{Establishing and verifying trust}

Advanced tax administration reforms combine an increasing trust in the taxpayer with a series of measures that collectively increase the capacity of the tax agency to assure itself at relatively low cost - that this trust is not being abused. The most visible manifestation of this trust is, especially in respect of corporate and private income and profits taxes and VAT, a growing reliance on self-assessment by the taxpayer. ${ }^{54}$ Tax administrations are increasingly able to cross-check the reliability of the information provided by taxpayers using two instruments that rely on the spread of ICTs: the allocation of unique tax identification numbers to each taxpaying unit; and data on assets, incomes or expenditures derived from 'third party' sources (banks, electricity providers, motor vehicle sales, property sales, credit card accounts, and company ownership and dividend payments). These instruments are not yet widely used in most low income countries. The same is true of the more significant change in tax practice to which they contribute: the shift to risk-based audit. Audit units traditionally have often been used to squeeze taxpayers suspected of having the capacity to pay more or as last minute means of helping the tax agency meets its revenue collection targets. Risk-based auditing involves targeting auditing resources on those taxpaying units that are identified, on the basis of statistical risk analysis that takes into account such factors as business type and individuals' records, as being especially likely to attempt significant levels of tax evasion. The immediate objective of risk-based auditing is not revenue collection per se, but preserving the integrity of the revenue system by deterring the most egregious tax evasion.

\subsection{Making tax paying easy and impersonal}

The third cluster of advanced tax administration reforms comprises a set of measures to make tax paying, including self-assessment, easier for taxpayers and to reduce the extent of

\footnotetext{
$52 \quad$ Kloeden provides some figures on the VAT taxpayer populations of eight Anglophone African countries for various single years between 2004 and 2009. On average, large taxpayers accounted for 4.8 per cent of the VAT taxpayer population and for 69 per cent of total VAT receipts (Kloeden 2011: 26).

53 For example, in Rwanda, regular campaigns to register and collect fees from what are in effect business licences from the numerous drivers of motorcycle taxis.

54 In the case of Customs collection, the equivalent of self-assessment is 'preferred trader' arrangements. Importers and exporters who enjoy this status on the basis of a clean record use the electronic transfer of their documentation to give Customs authorities prior notice of specific shipments, to obtain advanced clearance and thus to obviate the delays and threat of delays - embedded in the traditional system of physical verification of every cross-border consignment. Electronic tagging and sensing of goods will reinforce this trend.
} 
direct personal interaction relationships between them and tax collectors. The list includes: the simplification of tax systems and rates (fewer taxes, fewer rates for each tax, fewer exemptions); relocating tax offices or changing procedures to make it easier for taxpayers to register, file and pay - including using banks as collection agents; shifting these processes online; separating tax assessment and tax collection activities, both physically and functionally; providing quicker and fairer means of resolving disputes between tax collector and taxpayer; and providing more information to taxpayers about the procedures they are required to follow or how government spends their money. Many tax agencies in low income countries claim to be adopting or extending these kinds of practices (International Tax Dialogue 2010). We have little hard information on the extent of progress. As I explain in Section 2, there is no progress to report in respect of one of the items listed above: reducing the frequency of tax exemptions.

There is no expert consensus on the relative value of each of these many advanced tax administration practices, or on the extent to which they are synergistic with one another. It would be misleading to try to rank national tax authorities according to the extent to which they have adopted components of the package. These components are tools that can be used well or badly. The important conclusion is that there is available a menu of relatively well-tested tax administration reform options that are broadly appropriate to the circumstances of revenue raising in low income countries.

\section{The property tax issue ${ }^{5 s}$}

Property taxes may be levied on the ownership or occupation of land and of residential, commercial or industrial buildings. There is a broad consensus over property tax issues among tax specialists: ${ }^{56}$

- Property taxes are generally desirable because, compared to almost all alternative revenue sources they (a) do not significantly distort investment decisions, and (b) tend genuinely to fall on those better able to pay.

- They are consistently underused almost throughout the world, and have been declining in relative importance even in those countries where they were historically relatively important.

- Property taxes are particularly under-used in most low income countries.

We also have a good general understanding of why property taxes are especially under-used in low income countries. Three of the reasons are common to rich and poor countries:

- Because they tend to fall most on those best able to pay, property taxes are unpopular with the more politically active and influential social groups.

- Because property taxes are almost universally collected by and dedicated to financing local political jurisdictions (village, urban and city councils, district councils, etc.) they are very vulnerable to local elite dominance: rich and influential people are especially well placed to oppose them in the local political arenas in which they have a great deal of influence.

- Property taxes are very vulnerable to political and organisational inertia: the failure to organise periodic re-valuations to take account of increasing property values and to

\footnotetext{
55 There are a range of different types of property taxes, including in particular: (a) those that are levied on the ownership or occupation of a property; (b) those levied on changes in the legal ownership of a property; and (c) charges for the increased property values that result from public investment in infrastructure in the neighbourhood ('betterment levy')

56 The literature on property taxes in low income countries is massive. Anyone wishing to learn more about the issues could most usefully begin with Bahl et al. (2008) and Bird (2010, 2011).
} 
actually schedule the introduction of the tax in newly-developed urban areas. This inertia works in favour of their opponents. In many low income countries, property taxes are absurdly low. They may raise little revenue, but serve largely a rent-taking purpose: paying the salaries of the people who maintain the property registers and collect the taxes. ${ }^{57}$

Further, there are two specific reasons why property taxes are especially under-used in low income countries:

- Generally - although with a few conspicuous exceptions like Brazil - the polities of low income countries are strongly centralised in historical and comparative perspective. Sub-national governments have little authority and account for an unusually low proportion of public spending. In that situation, higher level governments may have little interest in supporting the development of revenue sources for local governments, and may indeed be actively opposed. Property taxes are the dominant single source of own revenue for local governments worldwide. ${ }^{58}$

- Improved ways of taxing property do not appear among the list of advanced tax administration practices discussed in Section 7 above. Because they are local taxes even in OECD countries, and politically increasingly unpopular, they have not received the attention of the authoritative organisations - the national tax and aid agencies in OECD countries, ${ }^{59}$ and international organisations like the IMF and the OECD - that have been influential in shaping the tax reform agenda in low income countries. Nearly all the energies that have gone into tax reform in low income countries have been directed at their national tax agencies (Fjeldstad and Moore 2008; Moore 2013).

From the organisational and logistical perspective, there would seem to be good prospects for increasing the tax take in low income countries by establishing more effective property tax systems, especially by taxing residential and commercial premises in towns and cities. The technology has moved in favour. Geographic information systems, that are anyway increasingly becoming valuable tools for many aspects of urban planning, potentially can greatly reduce the costs of establishing, maintaining and updating property registers. As in other areas of the tax business, the digitalisation of property tax accounts, billing and collection can in principle offer great efficiencies. Experiments in locations where property records are in a very poor condition suggest that 'presumptive' property taxes - that are only calibrated to a few gross indicators of property valuations such as the surface area of a property - can be both acceptable and efficient ways of getting a property tax system up and running (Jibao and Prichard 2012). ${ }^{60}$ There may be substantial broader governance benefits to providing sub-national governments with an independent and relatively buoyant revenue source.

Some of the obstacles to wider use of property tax seem straightforwardly political: the resistance of property owners and some higher levels of government; and the rent-taking currently practised by the people with the power to assess properties, schedule areas for the introduction of property tax, and collect the money. They typically put up effective resistance to attempts to introduce the digital technologies that would make it possible to cut out some

\footnotetext{
$57 \quad$ In some low income countries, property taxpayers find this tolerable because evidence of having paid the property tax may constitute useful evidence of property ownership or tenancy, or even of personal identity.

58 Their other main sources tend to be: (a) transfers from higher levels of government; and (b) a range of user charges and rentals - for water supply, use of public markets, shop rentals, etc.

The German aid agency, GIZ, is an exception.

In some countries where the real value of property taxes is very low, individual properties are still valued - and periodically re-valued - through complex, labour intensive formulae that take into account such factors as: total floor area; general condition of the building; location in relation to main roads or commercial areas; number and condition of trees within the property; whether the property is rented; whether it is used for commercial purposes; or whether the occupier falls into a needy category (e.g. widows).
} 
of the rent-taking. There is also a more nuanced institutional obstacle to more effective use of property taxes. Innovations in national and international taxation are crafted, tested and disseminated within a global 'epistemic community' of practising tax experts. These are the accountants, economists, lawyers, and tax administrators who work in the IMF, the OECD, consultancy companies, transnational auditing and professional services firms (e.g. the Big 4), associations of tax professionals, national tax administrations and ministries of finance. But this global epistemic community intersects barely at all with the more humble, local, diverse and numerous worlds of property tax specialists. These property tax worlds are populated by collectors, clerks and surveyors, rather than accountants, economists and lawyers. They speak many local languages rather than English, French or Spanish. Their successes are rarely celebrated, analysed or disseminated. They have few opportunities to interact - and therefore to learn - from one another.

\section{Conclusions}

What are the obstacles to increasing tax revenues in low income countries? This paper tries to answer that question by examining the literature on the topic and making informed judgements about the significance of various propositions. In summary, the conclusions are that tax takes are low in low income countries because:

- The structure of their economies makes revenue raising difficult (Section 1).

- Tax systems are used by a range of influential stakeholders for purposes other than official revenue raising, notably rent-taking (Section 2 ) and as a direct instrument of rule (Section 3).

- Patterns of political competition over fiscal issues between socio-economic interest groups may in different circumstances contribute to both lowering and raising the tax take (Section 4).

- The configuration of governing institutions may affect the ways in which fiscal decisions are made, and thus the tax take (Section 5).

- It is organisationally and politically difficult for the tax administrations of (smaller) low income countries effectively to tax the transnational economic transactions that comprise a steadily growing proportion of their potential revenue base (Section 6).

- Low income countries do not fully exploit the wide range of 'advanced' tax administration practices available to them (Section 7).

- For a mixture of reasons, property taxes are underused in low income countries even more than in other countries (Section 8).

These conclusions are only tentative. We are a long way from a confident, comprehensive understanding of the obstacles to increasing tax revenues in low income countries. Thorough and context-sensitive analysis of a great deal of data relating to a large number of low income countries over an extended time period could bring us closer to that understanding. Most of this data would have to be quantitative. The figures we have are inadequate in every dimension: too few, too aggregated, lacking historical depth, and insufficiently reliable. 


\section{References}

Amin, M. and Hoppe, M. (2013) Where Informal Procedures are Quasi-Formal - CrossBorder Trade between West and Central Africa, Africa Trade Policy Notes No. 37, Washington DC: World Bank

Ardanaz, M. and Scartascini, C. (2011) Why Don't We Tax the Rich? Inequality, Legislative Malapportionment, and Personal Income Taxation around the World, Working Paper Series No. 282, Washington DC: Inter-American Development Bank

Arnson, C.J., Bergman, M. and Fairfield, T. (2012) Taxation and Inequality in Latin America, Washington DC: Woodrow Wilson International Centre for Scholars

Bahl, R., Martinez-Vasquez, J. and Youngman, J. (eds) (2008) Making the Property Tax Work. Experiences in Developing and Transitional Countries, Cambridge MA: Lincoln Institute of Land Policy

Bates, R. (1977) Markets and States in Tropical Africa. The Political Basis of Agricultural Policies, Berkeley: University of California Press

Baunsgaard, T. and Keen, M. (2005) Tax Revenue and (or?) Trade Liberalization, Working Paper WP/05/112, Washington DC: International Monetary Fund

Bergman, M.S. (2003) 'Tax Reforms and Tax Compliance: The Divergent Paths of Chile and Argentina', Journal of Latin American Studies 35.3: 593-624

Best, M.H. (1976) 'Political Power and Tax Revenues in Central America', Journal of Development Economics 3.1: 49-82

Bezemer, D. and Headey, D. (2008) 'Agriculture, Development, and Urban Bias', World Development 36.8: 1342-1364

Bilangna, S., and Djeuwo, M. (2013) 'The Figures Culture in Cameroon Customs', in T. Cantens, R. Ireland and G. Raballand (eds), Reform by Numbers. Measurement Applied to Customs and Tax Administrations in Developing Countries, Washington DC: World Bank

Bird, R.M. (2012) Taxation and Development: What Have We Learned from Fifty Years of Research?, ICTD Working Paper No 1, Brighton: International Centre for Tax and Development

_ (2011) 'Subnational Taxation in Developing Countries. A Review of the Literature', Journal of International Commerce, Economics and Policy, 2.1: 139-161

(2010) Subnational Taxation in Developing Countries. A Review of the Literature, Policy Research Working Paper, Washington DC: World Bank

(2004) 'Administrative Dimensions of Tax Reform', Asia and Pacific Tax Bulletin, 10.3: 134-150

and Gendron, P-P. (2007) The VAT in Developing and Transitional Countries, Cambridge and New York: Cambridge University Press 
and Zolt, E.M. (2013) Taxation and Inequality in the Americas: Changing the Fiscal Contract?, Working Paper 13-15, Atlanta: Georgia State University, Andrew Young School of Policy Studies, International Centre for Public Policy

(2008) 'Technology and Taxation in Developing Countries: From Hand to Mouse', National Tax Journal, 61.4: 791-821

Boylan, D.M. (1996) 'Taxation and Transition. The Politics of the 1990 Chilean Tax Reform', Latin American Research Review, 31.1: 7-31

Cantens, T. (2012) Other People's Money and Goods: The Relationship between Customs Officers and Users in Some Countries of Sub-Saharan Africa, World Customs Organisation, mimeo

Ireland, R. and Raballand, G. (eds) (2013) Reform by Numbers. Measurement Applied to Customs and Tax Administrations in Developing Countries, Washington DC: World Bank

Raballand, G. and Bilanga, S. (2010) 'Reforming Customs by Measuring Performance: A Cameroon Case Study', World Customs Journal, 4.2: 55-73

Chaudhry, K.A. (1997) The Price of Wealth: Economies and Institutions in the Middle East, Ithaca and London, Cornell University Press

Choi, E.K. (2009) 'The Politics of Fee Extraction from Private Enterprises, 1996-2003', China Journal, 62: 79-102

Christian Aid (2010) Transfer Pricing and the Taxing Rights of Developing Countries, London

Cleeve, E. (2008) 'How Effective Are Fiscal Incentives to Attract FDI to Sub-Saharan Africa?', Journal of Developing Areas, 42.1: 135-153

Corbacho, A., Cibils, V.F. and Lora, E. (eds) (2013) More than Revenue. Taxation as a Development Tool, Washington DC: Inter-American Development Bank

Crandall, W. (2010) Revenue Administration: Autonomy in Tax Administration and the Revenue Authority Model, Technical Notes and Manuals, 10/12, Washington DC: Fiscal Affairs Department, International Monetary Fund

Cummings, R.G., Martinez-Vazquez, J., McKee, M. and Torgler, B. (2005) Effects of Tax Morale on Tax Compliance: Experimental and Survey Evidence, Working Paper 0516, Atlanta: Andrew Young School of Policy Studies, Georgia State University

Cuvelier, J., and Mumbunda, P.M. (2013) ‘Réforme Douanière Néolibérale, Fragilité Etatique et Pluralisme Normatif. Le Cas du Guichet Unique à Kasumbalesa', Politique Africaine, 129: 93-112

Cyan, M, Martinez-Vazquez, J. and Vulovic, V. (2013) Measuring Tax Effort: Does the Estimation Approach Matter and Should Effort be Linked to Expenditure Goals?, Working Paper 13-08, Atlanta: Georgia State University, Andrew Young School, International Center for Public Policy

Daunton, M. (2001) Trusting Leviathan. The Politics of Taxation in Britain 1799-1914, Cambridge: Cambridge University Press 
Dincecco, M. (2011) Political Transformations and Public Finances: Europe, 1650-1913, Cambridge: Cambridge University Press

Durand, F. (2002) State Institutional Development: Assessing the Success of the Peruvian Tax Reform, San Antonio: University of Texas,

Ebrill, L., Keen, M., Bodin, J-P. and Summers, V. (2002) 'The Allure of the Value-Added Tax', Finance and Development, 39.2

(2001) The Modern VAT, Washington DC: International Monetary Fund

Englebert, P. (2009) Africa: Unity, Sovereignty, and Sorrow, Boulder, Col. and London: Lynne Rienner

European Commission (2011) Transfer Pricing and Developing Countries. Final Report. Brussels: EuropeAid - Implementing the Tax and Development Policy Agenda, Brussels: European Commision

Fjeldstad, O-H. (2007) 'Corruption in Tax Administration. Lessons from Institutional Reforms in Uganda', in S. Rose-Ackerman (ed) International Handbook on the Economics of Corruption, London: Edward Elgar

and Moore, M. (2009) 'Revenue Authorities and Public Authority in Sub-Saharan Africa', Journal of Modern African Studies, 47.1: 1-18

(2008) 'Tax Reform and State Building in a Globalized World', in D. Braütigam, O$\mathrm{H}$. Fjeldstad and M. Moore (eds), Taxation and State-Building in Developing Countries: Capacity and Consent, Cambridge: Cambridge University Press

and Therkildsen, O. (2008) 'Mass Taxation and State-Society Relations in East Africa', in D. Braütigam, O-H. Fjeldstad and M. Moore (eds), Taxation and State-Building in Developing Countries: Capacity and Consent, Cambridge: Cambridge University Press

Fossat, P. and Bua, M. (2013) Tax Administration Reform in the Francophone Countries of Sub-Saharan Africa, Working Paper WP/13/173, Washington DC: International Monetary Fund

Fuest, C. and Riedel, N. (2012) 'Tax Evasion and Tax Avoidance: The Role of International Profit Shifting', in P. Reuter (ed), Draining Development? Controlling Flows of Illicit Funds from Developing Countries, Washington DC: World Bank

Gauthier, B. and Reinikka, R. (2006) 'Shifting Tax Burdens through Exemptions and Evasion: an Empirical Investigation of Uganda', Journal of African Economies, 15.3: 373-398

Gehlbach, S. (2008) Representation Through Taxation. Representation, Politics and Development in Postcommunist States, Cambridge: Cambridge University Press

Gemmell, N and Morrissey, O. (2005) 'Distribution and Poverty Impacts of Tax Structure Reform in Developing Countries: How Little We Know', Development Policy Review, 23.2: $131-44$ 
Gervasoni, C. (2010) 'A Rentier Theory of Subnational Regimes. Fiscal Federalism, Democracy, and Authoritarianism in the Argentine Provinces', World Politics, 62.2: $302-340$

Gupta, A.S. (2007) Determinants of Tax Revenue Efforts in Developing Countries, Working Paper WP/07/184, Washington DC: International Monetary Fund

Hart, A. (2010) 'Death of the Partisan? Globalization and Taxation in South America, 19902006, Comparative Political Studies, 43.3: 304-328

Imam, P.A. and Jacobs, D.F. (2007) Effect of Corruption on Tax Revenues in the Middle East, Working Paper WP/13/173, Washington DC: International Monetary Fund

IMF (2012) Fiscal Regimes for Extractive Industries: Design and Implementation, Washington DC: International Monetary Fund

- (2011) Revenue Mobilisation in Developing Countries, Washington DC: International Monetary Fund

International Tax Dialogue (2010) Revenue Administration in Sub-Saharan Africa, ITD Comparative Information Series No 1, Paris: International Tax Dialogue

James, S. (2010) Incentives and Investments: Evidence and Policy Implications, Washington DC: World Bank, Investment Climate Advisory Services

Jerven, M. (2013) Poor Numbers: How We Are Misled by African Development Statistics and What to Do About It, Ithaca: Cornell University Press

Jibao, S. and Prichard, W. (2012) Rebuilding Local Government Finance After Conflict: The Political Economy of Property Tax Reform in Post-Conflict Sierra Leone, ICTD Working Paper 12, Brighton: International Centre for Tax and Development

Joshi, A., Prichard, W. and Heady, C. (2012) Taxing the Informal Economy: Challenges, Possibilities and Remaining Questions, ICTD Working Paper No. 4, Brighton: International Centre for Tax and Development

Keen, M. (2012) Taxation and Development - Again, Working Paper WP/12/220, Washington DC: International Monetary Fund

(2007) VAT Attacks!, Working Paper WP/07/142, Washington DC: International Monetary Fund

and Lockwood, B. (2010) 'The Value Added Tax: Its Causes and Consequences', Journal of Development Economics, 92.2: 138-151

Kidd, M. (2010) Revenue Administration: Functionally Organized Tax Administration, Technical Notes and Manuals 10/10, Washington DC: Fiscal Affairs Department, International Monetary Fund

Klemm, A. (2009) Causes, Benefits, and Risks of Business Tax Incentives, Washington DC: International Monetary Fund

and Parys, S. (2012) 'Empirical Evidence on the Effects of Tax Incentives', International Tax and Public Finance, 19.3: 393-423 
Kloeden, D. (2011) Revenue Administration Reforms in Anglophone Africa Since the Early 1990s, Working Paper WP/11/162, Washington DC: International Monetary Fund

Knack, S. (2009) 'Sovereign Rents and Quality of Tax Policy and Administration', Journal of Comparative Economics, 37.3: 359-371

Land, A. (2004) Developing Capacity for Tax Administration: the Rwanda Revenue Authority, ECDPM Discussion Paper 57D, Maastricht: European Centre for Development Policy Management

Leite, C.A. (2012) 'The Role of Transfer Pricing in Illicit Financial Flows, in P. Reuter (ed), Draining Development? Controlling Flows of Illicit Funds from Developing Countries, Washington DC: World Bank

Levi, M. (1988) Of Rule and Revenue, Berkeley, Los Angeles and London: University of California Press

Li, Q. (2006) 'Democracy, Autocracy, and Tax Incentives to Foreign Direct Investors: A Cross-National Analysis', The Journal of Politics, 68.01: 62-74

Lopez-Calva, L.F. and Lustig, N. (2010) Declining Inequality in Latin America: A Decade of Progress?, Washington DC: Brookings Institution Press

Lundstøl, O., Raballand, G. and Nyirongo, F. (2012) Mining Revenues in Zambia and Tanzania: Fiscal design, technical capacity or political will?, ICTD Working Paper No. 9, Brighton: International Centre for Tax and Development

Madies, T. and Dethier, J-J. (2010) Fiscal Competition in Developing Countries. A Survey of the Theoretical and Empirical Literature, Policy Research Working Paper 5311, Washington DC: World Bank

Mann, M. (1993) The Sources of Social Power, Vol. 2: The Rise of Classes and NationStates, 1760-1914, Cambridge and New York: Cambridge University Press

Mkandawire, T. (2010) 'On Tax Efforts and Colonial Heritage in Africa', Journal of Development Studies, 46.10: 1647-69

Moore, M. (forthcoming) 'Taxation and Development', in C. Lancaster and N.V. d. Walle (eds), Handbook on the Politics of Development, Oxford and New York: Oxford University Press

(2013) Revenue Reform and State-Building in Anglophone Africa, ICTD Working Paper No. 10, Brighton: International Centre for Tax and Development

(2008a) 'Between Coercion and Contract: Competing Narratives on Taxation and Governance', in D. Braütigam, O-H. Fjeldstad and M. Moore (eds), Taxation and State-Building in Developing Countries: Capacity and Consent, Cambridge:

Cambridge University Press

(2008b) How Does Taxation Affect the Quality of Governance?, IDS Working Paper 280, Brighton: Institute of Development Studies 
Nitsch, V. (2012) 'Trade Mispricing and Illicit Flows', in P. Reuter (ed), Draining Development? Controlling Flows of Illicit Funds from Developing Countries, Washington DC: World Bank

OECD (2013a) Addressing Base Erosion and Profit Shifting, Paris: Organisation for Economic Co-operation and Development

(2013b) Analysis of Tax Expenditures in Ghana, Paris: OECD Tax and Development Program

(2009) Tax Administration in OECD and Selected Non-OECD Countries, Paris: OECD Forum on Tax Administration

Omoigui Okauru, I.M. (2013) 'Insights on the Reform of the Nigerian Tax System (20022012)', in The NLI White Papers Volume 2, Abuja: Nigeria Leadership Initiative

Pessino, C. and Fenochietto, R. (2010) 'Determining Countries' Tax Effort', Hacienda Public Espanola/Revista de Economia Publica, 194.4: 65-87

Prichard, W. (2009) The Politics of Taxation and Implications for Accountability in Ghana 1981-2008, IDS Working Paper 330, Brighton: Institute of Development Studies

Brun, J-F. and Morrissey, O. (2012) Donors, Aid and Taxation in Developing Countries: An Overview, ICTD Working Paper No. 6, Brighton: International Centre for Tax and Development

Prud'homme, R. (1992) 'Informal Local Taxation in Developing Countries', Environment and Planning C: Government and Policy, 10: 1-17

Rabelland, G. and Rajaram, A. (2013) Behavioural Economics and Public Sector Reform. An Accidental Experiment and Lessons from Cameroon, Policy Research Working Paper 6595, Washington DC: World Bank

Reuter, P. (ed) (2012) Draining Development? Controlling Flows of Illicit Funds from Developing Countries, Washington DC: World Bank

Seiferling, M. (2013) Recent Improvements to the Government Finance Statistics Yearbook Database in Response to Analytical Needs, Working Paper WP/13/15, Washington DC: International Monetary Fund

Steinmo, S. (1989) 'Political Institutions and Tax Policy in the United States, Sweden and Britain', World Politics, 41.4: 500-535

Tax Justice Network-Africa and Action Aid International (2012) Tax Competition in East Africa. A Race to the Bottom? Tax Incentives and Revenue Losses in Uganda, Nairobi and Johannesburg: Tax Justice Network-Africa and Action Aid International

Therkildsen, O. (2012) Democratisation in Tanzania. No Taxation without Exemptions, paper presented at American Political Science Association Annual Meeting, August 29September 2, 2012, New Orleans

(2004) 'Autonomous Tax Administration in Sub-Saharan Africa: The Case of the Uganda Revenue Authority', Forum for Development Studies, 31.1: 59-88 
Tilly, C. (2005) 'Regimes and Contention', in T. Janoski (ed), The Handbook of Political Sociology: States, Civil Societies, and Globalization, Cambridge: Cambridge University Press

(1992) Coercion, Capital and European States, AD 990-1992, Cambridge MA and Oxford UK: Blackwell

Timmons, J.F. (2005) 'The Fiscal Contract: States, Taxes and Public Services', World Politics, 57.4: 530-567

Titeca, K. (2009) 'The "Masai" and Miraa: Public Authority, Vigilance and Criminality in a Ugandan Border Town', Journal of Modern African Studies, 47.2: 291-317

and Kimanuka, C. (2012) Walking in the Dark. Informal Cross-Border Trade in the Great Lakes Region, London: International Alert

Torgler, B. (2005) 'Tax Morale in Latin America', Public Choice, 122.1: 133-157

- (2004) Tax Morale, Trust and Corruption: Empirical Evidence from Transition Countries, Working Paper 2004-5, Basel: Center for Research in Economics, Management and the Arts

Transparency International (2012) East African Bribery Index 2012, Nairobi: Transparency International

UNDESA (2013) Practical Manual on Transfer Pricing for Developing Countries, New York: United Nations Department of Economic and Social Affairs

Vázquez-Caro, J. and Bird, R.M. (2010) 'Benchmarking Tax Administrations in Developing Countries: A Systemic Approach', E Journal of Tax Research 9.1: 5-37

Yun Casalilla, B. and O'Brien, P.K. (eds) (2012) The Rise of Fiscal States: A Global History, 1500-1914, New York: Cambridge University Press

Zake, J. (2011) Customs Administration Reform and Modernization in Anglophone AfricaEarly 1990s to Mid-2010, Working Paper WP/11/184, Washington DC: International Monetary Fund

Zee, H.H., Stotsky, J.G. and Ley, E. (2002) 'Tax Incentives for Business Investment: A Primer for Policy Makers in Developing Countries', World Development, 30.9: 14971516

Zolberg, A.R. (1980) 'Strategic Interactions and the Formation of Modern States: France and England', International Social Science Journal, 32.4: 687-716 


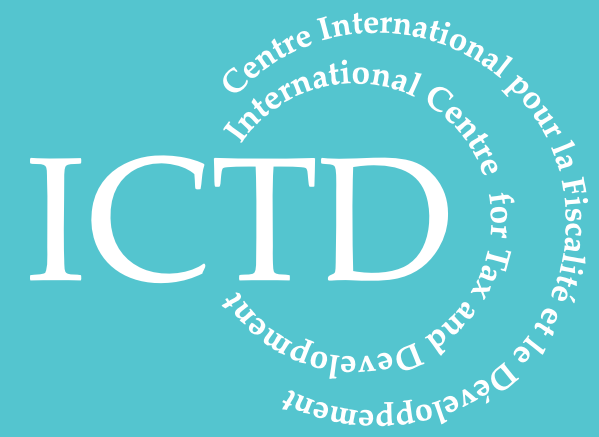

International Centre for Tax and Development at the Institute of Development Studies

Brighton BN1 9RE, UK

T: +44 (0) 1273606261

F: $+44(0) 1273621202$

E: info@ictd.ac

www.ictd.ac 